\title{
From Alpine-type sulfides to nonsulfides in the Gorno Zn project (Bergamo, Italy)
}

\author{
Nicola Mondillo ${ }^{1,2} \cdot$ Federica Lupone ${ }^{1} \cdot$ Maria Boni ${ }^{1,2} \cdot$ Michael Joachimski $^{3} \cdot$ Giuseppina Balassone $^{1}$. \\ Marcello De Angelis ${ }^{4} \cdot$ Simone Zanin ${ }^{4} \cdot$ Fabio Granitzio $^{5}$
}

Received: 18 March 2019 / Accepted: 7 July 2019 / Published online: 23 July 2019

(C) The Author(s) 2019

\begin{abstract}
Recent exploration of the Gorno $\mathrm{Zn}-\mathrm{Pb}$-Ag deposit in northern Italy identified 3.3 Mt of sulfides at $4.9 \% \mathrm{Zn}, 1.3 \% \mathrm{~Pb}$, and $27.2 \mathrm{~g} /$ t Ag (indicated+inferred resources), and a further mineralized nucleus of mixed sulfides-nonsulfides in the Val Vedra area, currently under evaluation. The ores are hosted in Triassic limestone and shale. Sulfides (sphalerite, Ag-bearing galena, minor pyrite, and chalcopyrite) paragenetically follow $\mathrm{Mn}$-Fe-bearing saddle dolomite and sparry calcite. The mineral association, and the carbon and oxygen isotope ratios of the sparry calcite (avg. $\delta^{13} \mathrm{C}=1.0 \pm 0.6 \%$ o V-PDB; avg. $\delta^{18} \mathrm{O}=19.63 \pm 1.25 \%$ o VSMOW), are in agreement with precipitation from hydrothermal fluids in a deep burial setting. Sulfide emplacement occurred before the Alpine orogeny, likely during the Early-Middle Jurassic, in analogy to other Alpine-type deposits. The nonsulfide ore formed at the expense of sulfides, and mainly consists of smithsonite, hydrozincite, hemimorphite, and cerussite. The C-Oisotope values of the early generations of $\mathrm{Zn}$-carbonates are characterized by $\delta^{18} \mathrm{O}$ between 24.1 and $26.8 \%$ o V-SMOW and $\delta^{13} \mathrm{C}$ ratios between -3.1 and $1.7 \%$ V-PDB. The later generations have lower $\delta^{18} \mathrm{O}\left(21.9\right.$ to $23.9 \%$ ) and lower $\delta^{13} \mathrm{C}(-6.2$ to $-3.9 \%$ ) . These compositions, as those measured on cerussite $\left(\delta^{13} \mathrm{C}=-6.3\right.$ and $-7.7 \%$; $\delta^{18} \mathrm{O}=14.0$ and $15.3 \%$ ) , agree with the formation of the nonsulfides in a supergene environment, under climatic conditions warmer than today. The $\delta^{18} \mathrm{O}$ decrease from early to late generations suggests progressive involvement of meteoric water sourced from higher altitudes. These characteristics indicate that the nonsulfides formed during the exhumation of the Gorno area from Miocene to Pliocene.
\end{abstract}

Keywords Zn sulfides $\cdot$ Nonsulfides $\cdot$ Alpine-type $\cdot \mathrm{C}$-O stable isotopes $\cdot$ Gorno $\cdot$ Climate $\cdot$ Exhumation $\cdot$ Weathering

Editorial handling: F. Melcher

Electronic supplementary material The online version of this article (https://doi.org/10.1007/s00126-019-00912-5) contains supplementary material, which is available to authorized users.

Nicola Mondillo

nicola.mondillo@unina.it

1 Dipartimento di Scienze della Terra, dell'Ambiente e delle Risorse, Università degli Studi di Napoli Federico II, Complesso Universitario di Monte S. Angelo, Via Cintia, Naples, Italy

2 Department of Earth Sciences, Natural History Museum, Cromwell Road, London, UK

3 GeoZentrum Nordbayern, University of Erlangen-Nuremberg, Schlossgarten 5, Erlangen, Germany

4 Alta Zinc Ltd., Via Roma 492, Oltre il Colle, Italy

5 Clariant Prodotti (Italia) SPA, Via Manzoni 37, Palazzolo Milanese, Italy

\section{Introduction}

The Gorno mining district, located in the central part of the Southern Alps, a few kilometers north of Milan and Bergamo (Lombardy, Italy) (Fig. 1), is characterized by several Zn$\mathrm{Pb}-(\mathrm{Ag})$ and fluorite-barite orebodies (Omenetto 1966; Vailati 1966). The Gorno deposit represents one of the numerous carbonate-hosted base-metal ore concentrations of the Alpine chain (Brigo et al. 1977), also known as "Alpine-type" $\mathrm{Zn}-\mathrm{Pb}$ mineralizations (Leach et al. 2003). The economically most significant deposits were located on both sides of the regional strike-slip fault zone of the "Insubric Line" (Schmid et al. 1989): Raibl, Salafossa, and Gorno (Italy) in the Southern Alps, and Bleiberg (Austria) and Mežica-Topla (Slovenia) in the Northern Alps (Leach et al. 2003; Schroll 2005,2006 ). The host rocks of the Alpine-type $\mathrm{Zn}-\mathrm{Pb}$ ores are mainly Triassic shallow water carbonates (Brigo et al. 1977). The origin and emplacement ages of the $\mathrm{Zn}-\mathrm{Pb}$ sulfide deposits are still controversial (e.g., Schulz 1964; Sangster 


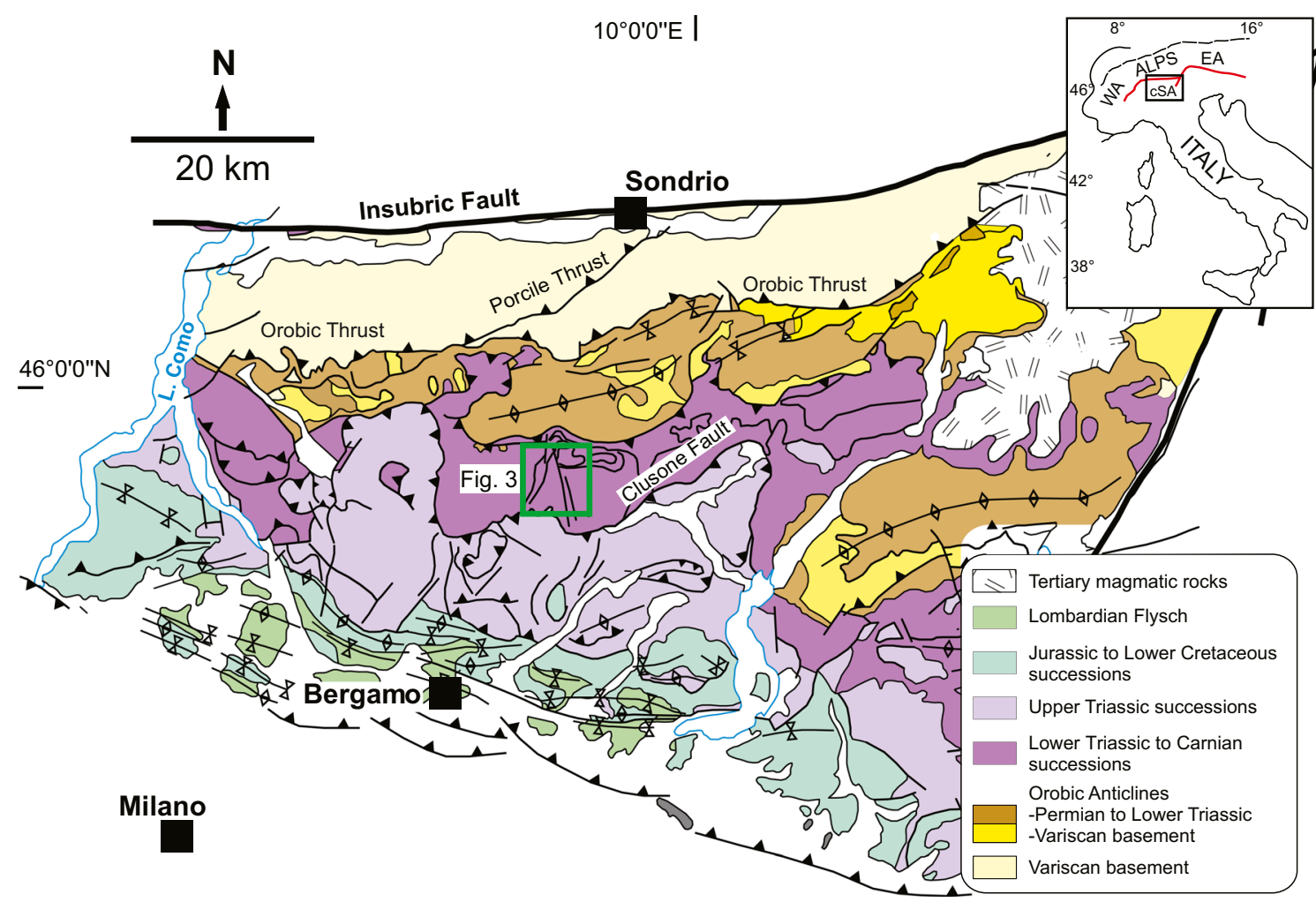

Fig. 1 Geological sketch of the central Southern Alps (northern Italy; modified from Zanchetta et al. 2015). The Gorno area is indicated by the green square (see enlargement in Fig. 3)

1976; Brigo et al. 1977; Kuhlemann 1995; Zeeh et al. 1998; Leach et al. 2003). The only radiometric ages were reported by Melcher et al. (2010) and Henjes-Kunst (2014), who dated the sphalerite from different horizons in the Bleiberg deposit. The resulting ages are between $204 \pm 3.2$ and $195 \pm 2.6 \mathrm{Ma}$, and are thus considerably younger than the Triassic host rocks. According to Leach et al. (2003), the Alpine-type Zn-Pb mineralizations formed from Late Triassic to Jurassic, when hydrothermal fluids derived from the Variscan chains (located north of the Austroalpine and South Alpine realms) progressively leached metals from the Paleozoic basement and its clastic cover. The sulfides were deposited in karst cavities and open fractures of the Triassic carbonate platforms located in the foreland zone, in a similar way as the typical Mississippi Valley-type (MVT) ores (Zeeh et al. 1998; Leach et al. 2003).

Besides sulfides, also high-grade "calamines" (i.e., oxidized $\mathrm{Zn}$ ore, also known as "nonsulfide ore"; Boni and Large 2003; Hitzman et al. 2003; Boni and Mondillo 2015) were exploited in all the above-mentioned mines. Even though the oxidized ores had a great role in enhancing the economic value of these deposits, little is known on their genesis, their age, and the environmental conditions during formation.

The ores in the Gorno mining district have been exploited since pre-Roman times. Modern exploitation began in the second half of the nineteenth century and was pursued by several mining companies for both "calamine" and sulfide ore. SAMIM (ENI) was the last company that conducted underground mining activities at Gorno until 1985, when the operations ceased. Currently, Alta Zinc Ltd. owns all permits and mining concessions in the area. In the last few years, this company started an exploration program, called the "Gorno Zinc Project," rehabilitating part of the historic $230 \mathrm{~km}$ of underground workings, with the aim of reopening the mines located north of the village of Oltre il Colle, in the Mt. Menna, Val Vedra, Mt. Arera, and Val Parina areas (www.altazinc.com) (Fig. 1). In 2015, in the Mt. Menna area, an extensive drilling campaign, performed underground from the old workings of the historic Val Vedra mine (see Vailati 1966), identified a massive orebody (called "Zorzone Resource"), located a few hundred meters under the Zorzone village. This sulfide orebody has $3.3 \mathrm{Mt} \mathrm{JORC}$ compliant indicated+inferred resources at $4.9 \% \mathrm{Zn} 1.3 \% \mathrm{~Pb}$ and $27.2 \mathrm{~g} / \mathrm{t} \mathrm{Ag}$ (cutoff grade of $1 \% \mathrm{Zn}$ ) (www.altazinc.com). Currently, Alta Zinc Ltd. is exploring other undeveloped areas of the historic mine workings, adjacent to the Zorzone orebody (Fig. 1), and has already identified other interesting targets in the historic Val Vedra mine, and in a "virgin" area (the Fontanone target; www. altazinc.com), located a few hundred meters below the old Val Parina-Mt. Arera mine (Vailati 1966; Rodeghiero and Vailati 1978). In several sectors of the mentioned areas, notable amounts of $\mathrm{Zn}-\mathrm{Pb}$ nonsulfide ore also occur, whose genesis is poorly constrained. The aim of the present paper is to provide a petrographic, mineralogical, geochemical, and $\mathrm{C}-\mathrm{O}$ stable isotope characterization of the $\mathrm{Zn}-\mathrm{Pb}$ nonsulfides occurring in the areas under exploration, with the purpose of shedding new light on 
their genesis, and on their relationships with the primary sulfide mineralization. In particular, considering the position of the Gorno area in a tectonically active mountain chain, the investigated nonsulfides are suitable for discussing crucial issues regarding the link between supergene weathering, upliftexhumation-erosion processes, and climate evolution. As shown by Arfè et al. (2018) for the nonsulfide deposits of the northern Andes, that link can be investigated through the Oisotopic compositions of $\mathrm{Zn}$-carbonates formed at the expense of preexisting sulfides.

\section{Geological setting}

\section{Regional geology and tectonic evolution}

The Gorno area is located in the western-central part of the Southern Alps, also known as Orobic Alps (Lombardy, Italy) (Fig. 1). The Southern Alps are a low- to non-metamorphic south-verging thrust belt, separated from the north-verging (mainly metamorphic) Alps by the Insubric Line, a dextral transpressive fault, active mainly since the Oligocene (Schmid et al. 1989). The Insubric Line bounds the northern part of the Southern Alps, which consists of pre-Alpine basement units tectonically thrusted above basement-cored anticlines (known as Orobic anticlines), mostly made up of Permo-Carboniferous lithologies (Zanchetta et al. 2015). Moving southward, the southern limbs of the Orobic anticlines are overlain by back-thrusts of Lower Triassic to Carnian prevailingly carbonate successions. These Lower Triassic to Carnian thrust sheets are overlain by imbricated Upper Triassic sedimentary rocks, which are also overthrusted on the Jurassic and Cretaceous units located in proximity of the Po plain (Zanchetta et al. 2015).

The Early Permian to Paleogene succession of the Southern Alps records a complex basin evolution spanning from the end of the Variscan orogeny, through Mesozoic rifting and drifting to the onset of the Alpine orogeny in the Cretaceous (Bertotti et al. 1993; Berra and Carminati 2010). The southern Alpine basins were affected by two major extensional events in the Norian (i.e., Jadoul et al. 1992) and Early Jurassic (i.e., Gaetani 1975; Winterer and Bosellini 1981; Bernoulli 2007), which were both responsible for the development of $\mathrm{N}-\mathrm{S}$ striking normal faults that eventually led to the opening of the Alpine Tethys during the Middle Jurassic (Zanchi et al. 1990). In the southern Alpine domain, these N-S-striking structures were reactivated during the earliest stages of the Alpine compression (Late Cretaceous, 80-68 Ma), which led to the emplacement of the basement and the Lower to Middle Triassic sediment thrust sheets. A second deformation phase (55-45 Ma) was associated with the southward propagation of the Orobic anticline system (Zanchetta et al. 2015). In the Gorno area (Fig. 1), the reactivation of the preexisting
N-S tectonic lineaments, confined within the Middle Triassic to Carnian units, led to the formation of the so-called GremVedra Transverse Zone (Zanchi et al. 2012).

Between 40 and $35 \mathrm{Ma}$, several igneous plutons intruded the eastern sectors of the central-southern Alps, whereas magmatic dikes intruded the Lower Triassic-Carnian units in the central sectors of the belt. Fission-track ages obtained on these magmatic rocks suggest that intrusions occurred in already exhumed country rocks (D'Adda et al. 2011); therefore, the presently exposed Southern Alps were largely structured and exhumed in pre-late Eocene times (Zanchetta et al. 2015). The latest post-Eocene compressional phase (Oligocene to Upper Miocene) allowed structuring the Southern Alps foreland belt buried beneath the Po Plain. During this period of southward migration of the deformation front, the already structured northern sectors of the Southern Alps, being passively transported toward the south, were not affected by further deformation (Zanchetta et al. 2015).

The late Cenozoic evolution of the central Southern Alps was characterized by the diachronous exhumation of the major structural units, with the Lower Triassic-Carnian successions recording an exhumation pulse of Burdigalian age (20$15 \mathrm{Ma}$ ), whereas the northern basement units and the Orobic Anticlines were affected by an exhumation pulse in the Tortonian (10-7 Ma; Zanchetta et al. 2015). The Tortonian exhumation was associated with a fast erosion rate $(1 \mathrm{~km} /$ m.y.), compared to the preceding and later minor erosion rates (0.1-0.2 km/m.y.; Zanchetta et al. 2015).

\section{Stratigraphy of the Gorno area}

The Gorno area is dominated by Lower Triassic to Carnian carbonate rocks (Fig. 2). At the base of the succession, the Anisian to Ladinian section shows a few local variations with subtidal and peritidal carbonates (Angolo Limestone Formation, 250 $300 \mathrm{~m}$ thick), basinal marly limestones (Prezzo Limestone Formation, 10-15 m), and platform carbonates (Esino Limestone Formation, 600-700 m) (Jadoul et al. 2012). In the late Ladinian, tectonic and volcanic-explosive activities caused uplift, erosion, and karstification of the Esino carbonates. The successive Calcare Rosso Formation is the product of subaerial exposure and repeated meteoric diagenesis (Jadoul and Omenetto 1980; Jadoul and Rossi 1982). The Calcare Rosso is overlain by peritidal (Breno Formation) and dark subtidal limestones (Calcare Metallifero Bergamasco Formation, 80-100 m), followed in turn by $150-300 \mathrm{~m}$ of marls and limestones (Gorno Formation), laterally interfingering with deltaic sandstones (Val Sabbia Sandstones Formation). Close to the Ladinian-Carnian boundary, tuffites and other volcanic deposits are interbedded on the top part of the Esino Limestone Formation and in the Breno Formation, pointing to the mentioned coeval volcanic activity in the surrounding areas. The Gorno Formation is followed by the terrigenous-carbonate deposits of the San Giovanni 
Fig. 2 Stratigraphy of the Triassic successions of Southern Alps (modified from Hou et al. 2016). The yellow star indicates the position of the $\mathrm{Zn}-\mathrm{Pb}$ ores

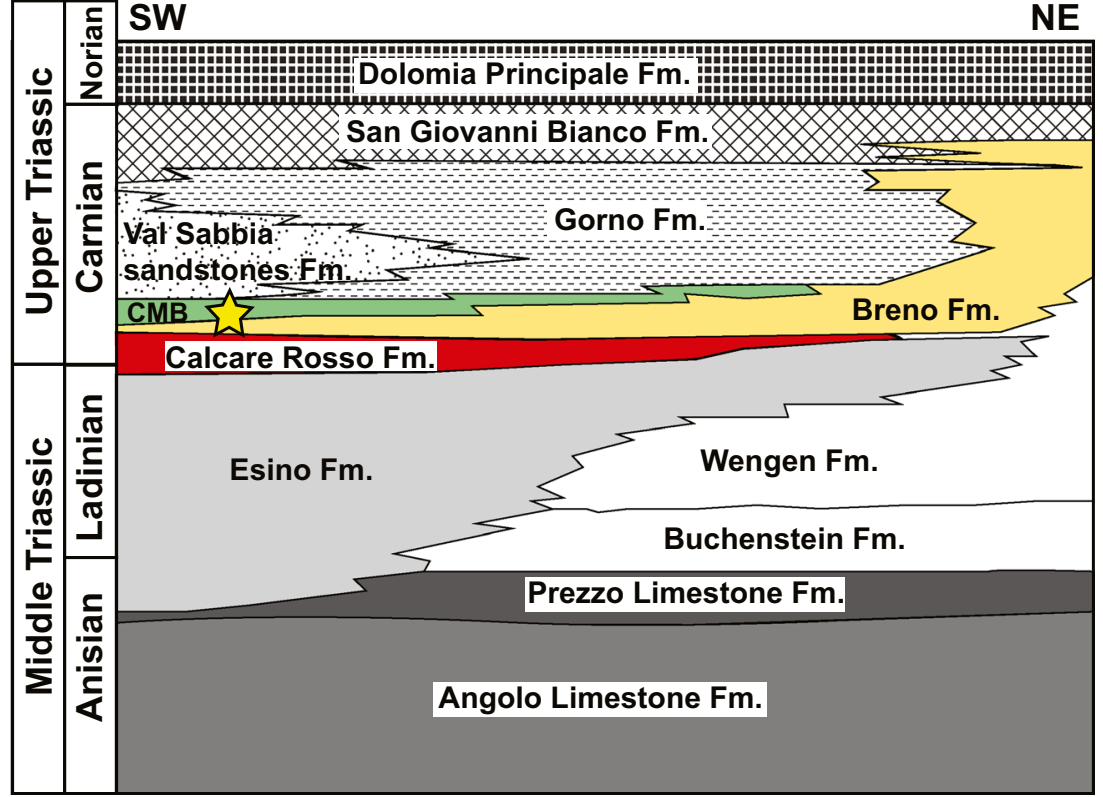

Bianco Formation, which include gypsum layers. The overlying Upper Triassic succession mainly consists of the carbonate platform system of the Dolomia Principale Formation, and of its coeval basinal facies (Jadoul et al. 2012).

The Gorno $\mathrm{Zn}-\mathrm{Pb}$ mineralized bodies occur in the lower Carnian Calcare Metallifero Bergamasco Formation (CMB) (Fig. 2), which in the study area (Oltre il Colle district) consists of well-stratified dark limestones (average thickness 10 to $35 \mathrm{~m}$ ), with marly interbeds (Rodeghiero and Vailati 1978). The CMB is locally overlain by a horizon of black bituminous clayey sediments ("black shales" after Assereto et al. 1977), which represent the basal part of the Gorno Formation, interfingering below the Val Sabbia Sandstones Formation. These black shales are called the "Basal Tongue" of the Gorno Formation (Jadoul and Omenetto 1980; Jadoul et al. 2012; Zanchi et al. 2012).

\section{General features of the ore deposits in the Gorno district}

The ore deposits of the Gorno district are distributed between the Seriana (east) and the Brembana Valleys (west) (Omenetto 1966), over an area extending E-W for more than $30 \mathrm{~km}$ and $\mathrm{N}-\mathrm{S}$ for $20 \mathrm{~km}$ (Jadoul and Omenetto 1980). They mainly consist of (1) $\mathrm{Zn}-\mathrm{Pb}$ ores in the Val Vedra, Val Parina, Mt. Arera, and Val Riso-Mt. Trevasco areas (Omenetto 1966); (2) dominant fluorite ores in the Paglio Pignolino-Dossena area (Jadoul and Omenetto 1980); (3) barite ores in the Brembana Valley; and (4) fluorite-barite deposits, with subordinate $\mathrm{Zn}-\mathrm{Pb}$ ores in the Presolana area (Assereto et al. 1976, 1978; Brigo et al. 1977; Rodeghiero 1977; Jadoul and Omenetto 1980). These ores mainly occur as stratiform bodies in the CMB Formation, at the contact with the black shales of the "Basal Tongue" of the Gorno Formation, or as discordant bodies in the limestones of the underlying Breno Formation (Omenetto 1966; Vailati 1966; Rodeghiero and Vailati 1978).

The $\mathrm{Zn}-\mathrm{Pb}$ ore deposits (this study), located in the historically known "Val Vedra mine," between the Mt. Menna and Val Vedra areas (Vailati 1966) were partly exploited in the 1970s through underground mining. The presently explored mineralized bodies extend for an E-W strike of about $1000 \mathrm{~m}$ and a N-S down-dip length of about $250 \mathrm{~m}$ (www.altazinc. com) (Figs. 3 and 4). At the top, the Val Vedra orebodies are confined and deformed by the sub-horizontal, south-verging, low-angle Pian Bracca thrust fault (Omenetto 1966; Vailati 1966); to the east, the mineralization is bound by the N-Sdirected Pezzel fault, whereas to the west, the orebodies are confined by a NW-SE-directed normal fault (called "Vedra fault" by Vailati 1966). The Zorzone orebody is near the above-mentioned Val Vedra mineralized bodies, being located on the west side of the Vedra fault of Vailati (1966) and is confined upward by the Mt. Menna thrust plane (that could represent the uplifted westerly extension of the Pian Bracca thrust fault; see Rodeghiero and Vailati 1978). The Fontanone orebody (www.altazinc.com), located in an unmined zone below the historic Val Parina-Mt. Arera mine (see Vailati 1966), was first intercepted during the excavation of the Riso-Parina tunnel at the level $550 \mathrm{~m}$ a.s.l. (Rodeghiero and Vailati 1978), and would correspond to the easterly extension of the Val Vedra orebodies that have been shifted downwards by the Pezzel fault (Rodeghiero and Vailati 1978; Zanchi et al. 2012) (Figs. 3 and 4).

In the historic Val Vedra and Val Parina mines, the ores occur with three main geometric shapes (Omenetto 1966, 1979; Vailati 1966; Rodeghiero and Vailati 1978): (1) 

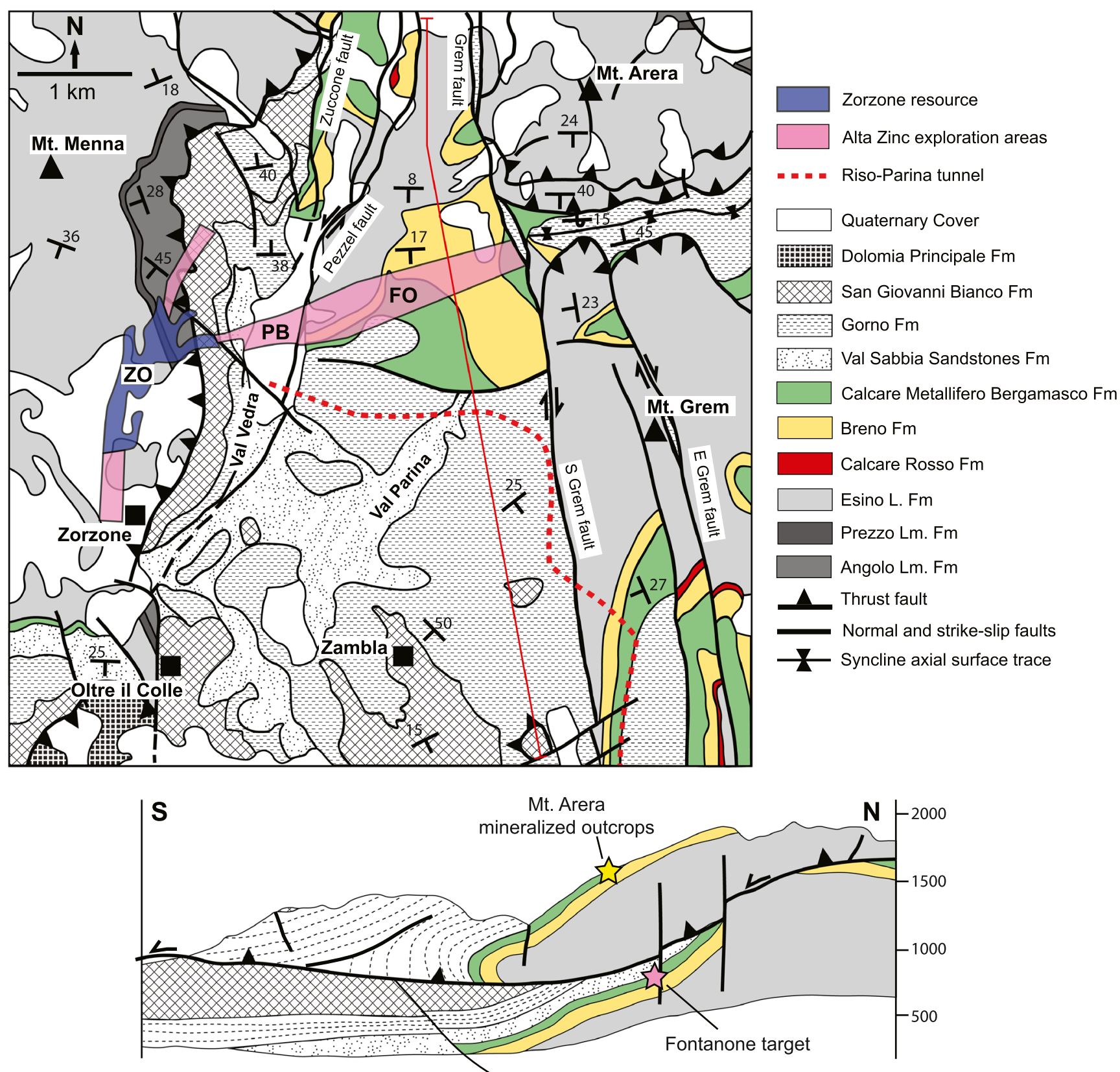

Fig. 3 Geological map and schematic section of the Gorno area (modified from Zanchi et al. 2012). Alta Zinc underground exploration

orebodies sub-concordant with the stratification of the limestones; (2) fault-hosted bodies, mainly characterized by nonsulfides associated with sulfides; and (3) crevasse-type bodies, containing both sulfides and nonsulfides, which have been interpreted by the above authors as karst-filling concentrations. The sulfide ores occurring in the Gorno area contain reddish-yellow to brown sphalerite associated with finegrained galena, in veinlets or disseminated within sphalerite or scattered in the limestone (Omenetto 1966). Pyrite and marcasite are ubiquitous. Minor chalcopyrite is associated with sphalerite or with galena. $\mathrm{Cu}-\mathrm{Sb}$-As sulfosalts (tetrahedrite, tennantite, bournonite, As-bournonite, jamesonite, and areas: $\mathrm{FO}=$ Fontanone, $\mathrm{PB}=$ Pian Bracca, $\mathrm{ZO}=$ Zorzone resource $($ from Alta Zinc Ltd.)

boulangerite) are quite frequent as inclusions in galena. Calcite is the most abundant gangue mineral and commonly occurs as coarse white crystals, associated with sulfides. Calcite is also accompanied by rhombohedral dolomite crystals and by rare siderite (Omenetto 1966).

The sulfides are commonly oxidized to nonsulfides. These mostly consist of smithsonite, which replaces sphalerite or occurs as gray or yellow-brownish concretions, accompanied by botryoidal aggregates of hydrozincite and by microcrystalline hemimorphite filling cavities on smithsonite and hydrozincite surfaces. Cerussite and anglesite replace galena. The secondary sulfides covellite and chalcocite are locally encountered in 


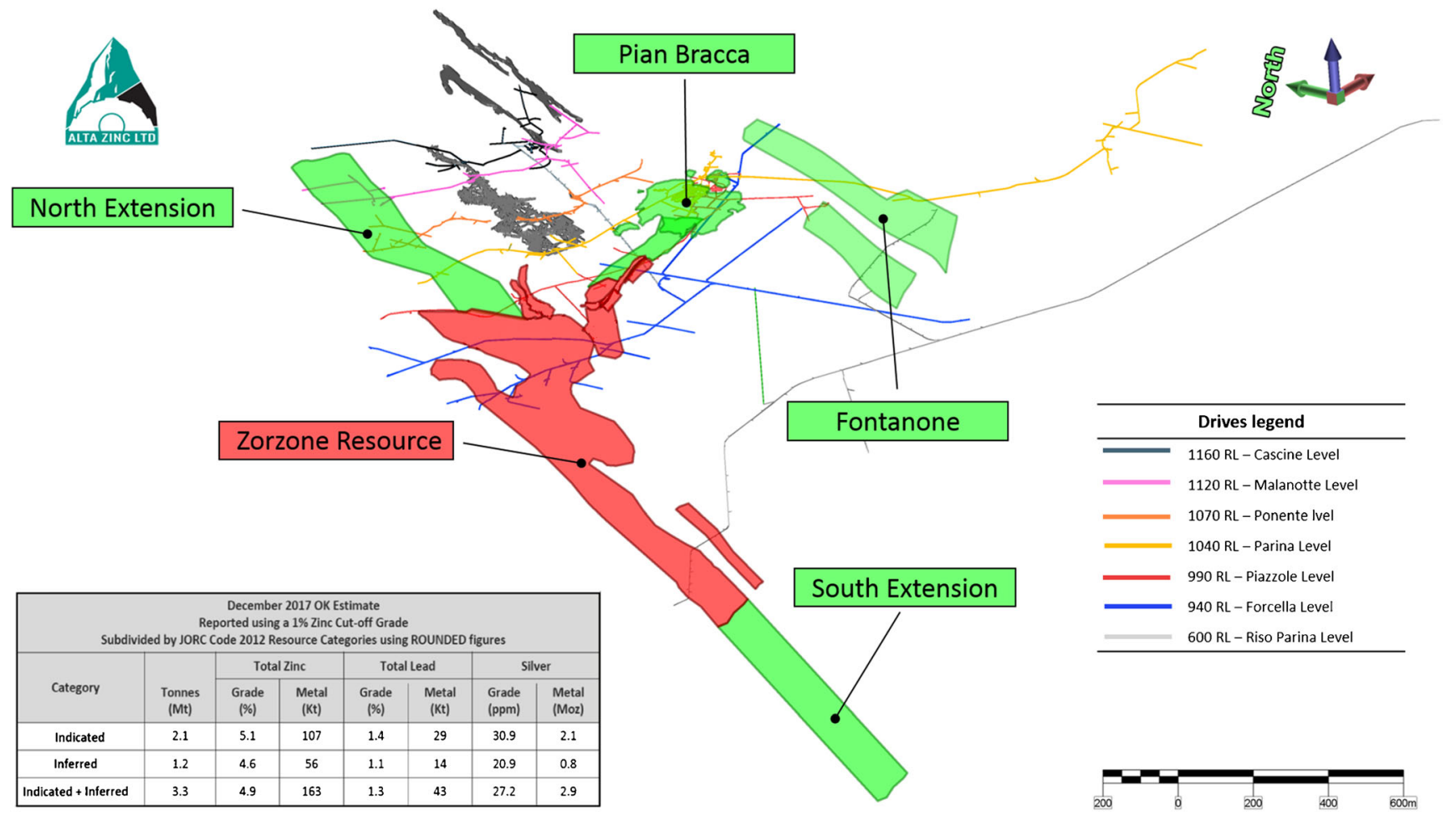

Fig. 4 Sketch of the 3D model of the Gorno Zn project, showing the Zorzone orebody, the Fontanone target and the mine levels as named in text (Alta Zinc Ltd.)

association with cerussite and smithsonite. Covellite is more abundant than chalcocite and occurs as replacement of $\mathrm{Cu}-$ bearing minerals, especially of As-bournonite (Omenetto 1966). Bindheimite replaces the Sb-bearing sulfosalts (e.g., tetrahedrite, jamesonite, and bournonite) and is generally associated with cerussite. Minor wulfenite, malachite, azurite, and aurichalcite may also occur together with smithsonite and hydrozincite (Omenetto 1966).

The Gorno sulfide ores were initially interpreted as synsedimentary precipitates, genetically associated with the Middle Triassic volcanism related to the advanced Tethyan rifting. This interpretation was justified by the stratigraphic control of the $\mathrm{Zn}-\mathrm{Pb}$ mineralizations at a regional scale or by the strict association between sulfides and black shales (e.g., Ehrendreich 1960; Vaché 1962; Di Cobertaldo and Comisso 1964). However, other features, as for example the structural control on the sulfide mineralization, in particular the location of sulfide ore minerals in fault-breccias associated with $\mathrm{N}-\mathrm{S}$-striking normal faults, or the occurrence of sulfidecemented dissolution and collapse breccias (see Leach et al. 2003), or the abundance of Cu-Sb-As sulfosalts, were considered as evidence for an epigenetic origin of the sulfides (Zucchetti 1960; Omenetto 1966; Vailati 1966; Rodeghiero and Vailati 1978). In this case, the sulfide ores should have been formed after the deposition of the Gorno and Val Sabbia Formations, in a period comprised between the Late Triassic and Late Cretaceous.

\section{Materials and methods}

\section{Sampling strategy}

The analyzed samples were collected in the historic Val Vedra mine of the Gorno $\mathrm{Zn}-\mathrm{Pb}$ project, in several levels of the old underground operations where Alta Zinc Ltd. is currently exploring: Ponente level (1070 m a.s.1.), Pian Bracca-Parina W level (1040 m a.s.1.), Parina E level (1027 m a.s.l.), Pannello 8 and Piazzole level (990 m a.s.1.), and Forcella level (940 m a.s.l.). A few samples were also collected from the old openpit workings of Mt. Arera. Since the main aim of this study was the investigation of the mineralogical and geochemical characteristics of the nonsulfide mineralization, particular attention was given to sample in the Piazzole level (990 m a.s.l.) that is characterized by the prevailing occurrence of oxidized $\mathrm{Zn}-\mathrm{Pb}$ ore. However, sulfide ores have been also described in this level and in the other levels, where they are texturally associated with nonsulfides. The location and a brief description of the collected samples are given in ESM Table 1. The main characteristics of the sampling areas are outlined below.

- Ponente level (1070 $\mathrm{m}$ a.s.l.): the mineralization is located in the footwall of the low-angle Pian Bracca thrust fault. It is hosted by both black carbonaceous shales at the contact between the CMB and the "basal tongue" of the Gorno Formation and the Breno Formation limestone, in form of 
veins and as cement of fault breccias. The mineralization occurs generally parallel to the bedding or locally discordant in fault breccias. Sulfide ores and calcite gangue appear deformed (Fig. 5a), whereas the nonsulfide minerals, which directly replace the sulfides and fill open spaces, are undeformed (Fig. 5b).

- Pian Bracca-Parina W level (1040 m a.s.1.): the mineralization is developed close to the low-angle Pian Bracca thrust fault. The mineralization is hosted in a graphitic and carbonatic mélange, strongly tectonized, at the contact between the CMB and the "basal tongue" of Gorno Formation. It mainly consists of fine-grained sphalerite and galena that are both recrystallized and concentrated in multiple sheared lenses with fluidal texture, isoclinal folds and boudins, as effect of the deformation at the basis of the thrust zone (Fig. 5c).

- Parina E level (1027 m a.s.1.): the sulfide mineralization is hosted in the black shales of the CMB Formation. It mainly consists of ribbon-shaped sphalerite and disseminated galena, associated with calcite gangue (Fig. 5d).

- Pannello 8 (990 $\mathrm{m}$ a.s.1.): in this area, the sulfide mineralization is hosted by the Breno Formation limestone. The sulfides occur as cement of the centimetric-to-metric carbonate clasts of a typical "dissolution-collapse breccia" (Fig. 5e). Massive sphalerite was locally precipitated in veins parallel to the limestone layering, or in tension veins perpendicular to the beds.

- Piazzole level (990 m a.s.1.): nonsulfide orebodies, hosted in $\mathrm{N}-\mathrm{S}$ oriented fault breccias in the Breno Formation limestones, prevail over sulfides. Remnants of sphalerite and galena, as well as the macrocrystalline calcite occurring in veins, are commonly deformed. Clearly undeformed nonsulfide minerals directly replace sulfides and fill open-spaces within the fault breccia (Fig. 5f).

- Forcella level (940 m a.s.1.): the sulfide ores, representing the "Zorzone resource," have been sampled in this level. The mineralized bodies consist almost exclusively of sphalerite hosted in black shales, at the contact between the CMB and the "basal tongue" of the Gorno Formation. Sphalerite occurs as centimetric crystals disseminated in the black shales or as decimetric masses surrounded by shales, resembling "macro-porphyroblast" structures. Few samples from a peripheral oxidized mineralization have been collected too.

\section{Analytical methods}

X-ray diffraction (XRD) analyses were carried out on quarters of the samples that were also used for chemical analyses. The samples were first ground with a mill, and then using an agate mortar and pestle. XRD analyses were carried out with a Seifert-GE
ID3003 diffractometer (Dipartimento di Scienze della Terra, dell'Ambiente e delle Risorse, Università di Napoli, DiSTAR), with $\mathrm{CuK} \alpha$ radiation, Ni-filtered at $40 \mathrm{kV}$ and $30 \mathrm{~mA}, 3-70^{\circ} 2 \theta$ range, step scan $0.05^{\circ}$, time $5 \mathrm{~s} / \mathrm{step}$, and the RayfleX (GE) software package; a silicon wafer was used to check the instrumental setting. Sample holder was a zero-background plate of quartz crystal, cut and polished $6^{\circ}$ of the $c$-axis.

Optical microscopy (OM) and scanning electron microscopy with energy-dispersive X-ray spectroscopy (SEM-EDS) analysis were performed on polished thin sections. Scanning electron microscopy was performed with a JEOL JSM5310 (Dipartimento di Scienze della Terra, dell'Ambiente e delle Risorse, Università degli Studi di Napoli, DiSTAR). Qualitative EDS investigations were performed with the INCA X-stream pulse processor and the 4.08 version Inca software (Oxford Instruments detector), interfaced with the JEOL JSM5310. Analytical errors are 1\% relative for major elements and 3\% relative for minor elements. 3D SEM was applied in order to obtain high-resolution images and information on the morphology of specific nonsulfide minerals.

Whole-rock chemical analyses (A) of major $(\mathrm{Zn}, \mathrm{Pb}, \mathrm{Fe}$, $\mathrm{Ca}, \mathrm{Mg}, \mathrm{Si}, \mathrm{Al}, \mathrm{Na}, \mathrm{K}, \mathrm{P}, \mathrm{Mn}$ ) and minor elements (Ga, Ge, Mo, Cu, Ag, Ni, Co, As, U, Th, Sr, Cd, Sb, Bi, V, La, Cr, Ba, W, Sc, Tl, Se, Rb, Sn, Zr, Y, Ce, In) of 27 mineralized samples were carried out on identical powder splits to those used for the XRPD analyses by Bureau Veritas Commodities Canada Ltd. (Vancouver, Canada). Ten grams were used for analysis on the LF725 package (fusion/X-ray fluorescence spectroscopy (XRF)). Samples with high Zn amounts (greater than 24\%) were run for overlimits with the LF726 package, in which the samples are fused with $\mathrm{Li}_{2} \mathrm{~B}_{4} \mathrm{O}_{7} / \mathrm{LiBO}_{2}$ fluxes to be subsequently analyzed by XRF. Minor elements were assayed by using the AQ250-EXT (ultratrace aqua regia plus ICP-AES and MS) package. Gallium and Ge were analyzed using the GC204-Ge \& Ga package, which involves a closed vessel procedure, to prevent element loss during the $\mathrm{HF}+\mathrm{AR}$ digestion, followed by ICP-MS analysis.

Carbon and oxygen isotope analyses were performed on carbonate minerals, hand-picked from different zones of the mineralized samples, as well as on calcite and dolomite from the host rock. The analyses were carried out at the GeoZentrum Nordbayern of the University of Erlangen-Nürnberg (Germany). Powdered carbonate samples were reacted with phosphoric acid at $70^{\circ} \mathrm{C}$, using a GasBench II connected to a Thermo Finnigan V Plus isotope ratio mass spectrometer. The carbon and oxygen isotope results are expressed as delta values in permil (\%o), relative to Vienna Peedee belemnite (V-PDB) and Vienna standard mean ocean water (V-SMOW), respectively, by assigning a $\delta^{13} \mathrm{C}$ value of $+1.95 \%$ o to NBS19 and $46.6 \%$ to LSVEC and $\delta^{18} \mathrm{O}$ values of $-2.20 \%$ to NBS19 and $-23.2 \%$ to NBS18. Reproducibility was checked by replicate analysis of laboratory standards and was better than \pm $0.07 \%$ o $(1 \sigma)$ for both carbon and oxygen isotope analyses. 

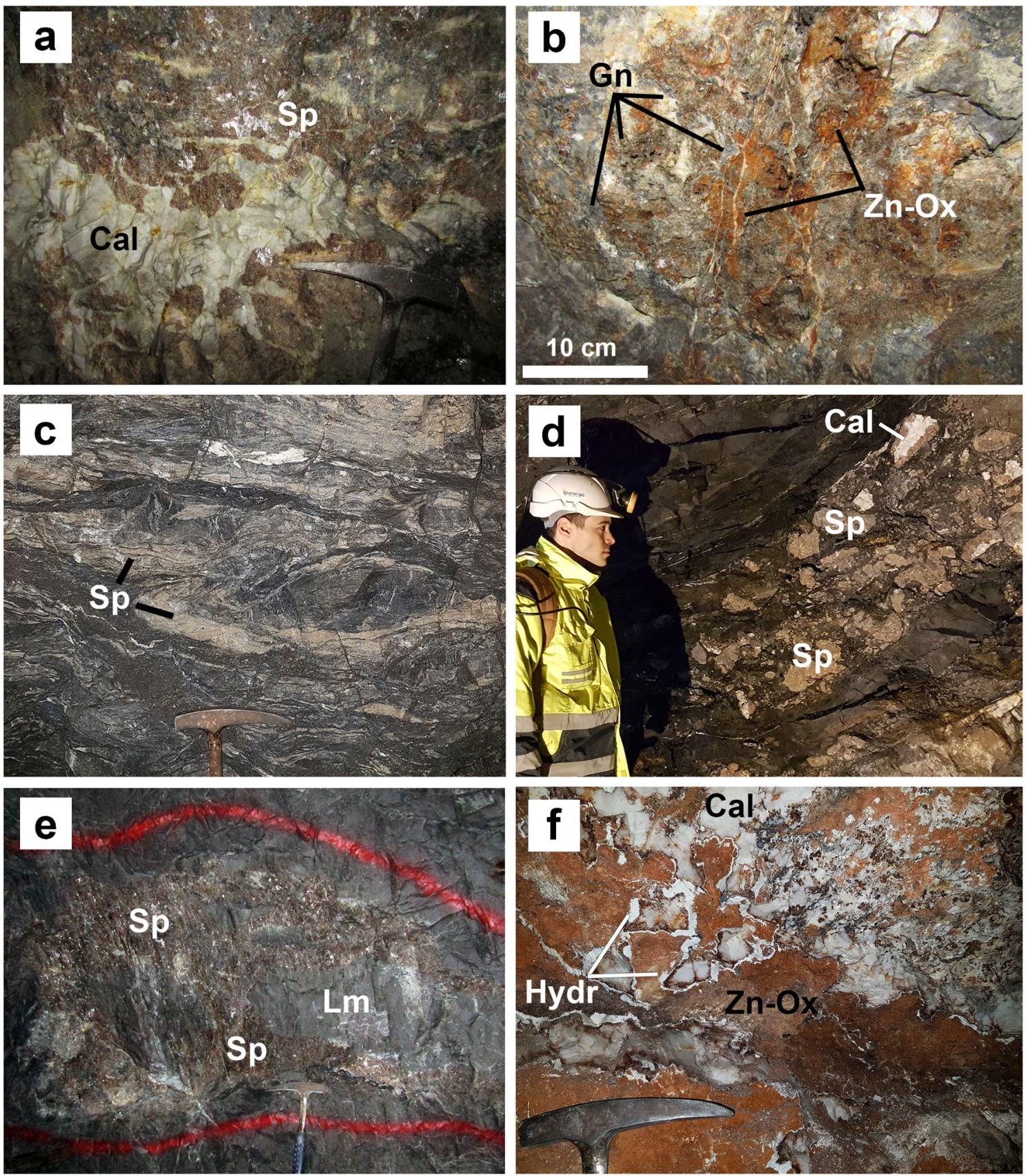

Fig. 5 Mineralized occurrences in the Gorno $\mathrm{Zn}$ project (former Val Vedra mine). a Ponente level (1070 m a.s.1.): deformed and recrystallized sulfides and calcite gangue. b Pian Bracca-Parina W level (1040 $\mathrm{m}$ a.s.1.): undeformed nonsulfide minerals, directly replacing the sulfides and filling open-spaces. c Pian Bracca-Parina W level $(1040 \mathrm{~m}$ a.s.l.): fine-grained sphalerite recrystallized and concentrated in multiple sheared lenses with fluidal texture. d Parina E level (1027 m a.s.l.):

Oxygen isotope values were corrected using the phosphoric acid fractionation factors given by Kim et al. (2007) for calcite and Gilg et al. (2003) for smithsonite and cerussite. As the phosphoric acid fractionation factor for hydrozincite has not been determined yet, we adopted the smithsonite acid fractionation factor (Gilg et al. 2003) as in earlier studies (e.g., Mondillo et al. 2014; Arfè et al. 2017, 2018).

ribbon-shaped sphalerite clasts, associated with recrystallized calcite gangue, floating in black shales. e Pannello 8 (990 m a.s.1.): dissolution-collapse breccia cemented by sphalerite. f Piazzole level (990 m a.s.l.): undeformed nonsulfide minerals directly replacing sulfides; it is possible to see remnants of original calcite gangue. $\mathrm{Cal}=$ calcite, $\mathrm{Gn}=$ galena, $\mathrm{Hydr}=$ hydrozincite, $\mathrm{Lm}=$ limestone, $\mathrm{Sp}=$ sphalerite, $\mathrm{Zn}-\mathrm{Ox}=$ mixed zinc nonsulfides

\section{Results}

\section{Mineralogy and petrography}

The sulfides from the Ponente, Pian Bracca-Parina W, Parina E, Pannello 8, and Forcella levels, as well as from Mt. Arera, consist of massive yellow-reddish sphalerite and fine-grained galena in 
veinlets (Fig. 6a). The samples from the Ponente and Pian Bracca-Parina $\mathrm{W}$ levels, which are located in the footwall of a low-angle thrust fault, show the typical deformation features of shear zones, with both sulfides and their gangue carbonates strongly deformed in sigmoidal structures (Fig. 6b). In other areas (e.g., Pannello 8, Piazzole and Forcella levels), which are located deeper in the footwall of the thrust fault, the samples show less intense deformation, a feature occurring also where the ore bodies are hosted in the limestones of the Breno Formation. Sphalerite is characterized by low contents of $\mathrm{Fe}(\sim$ $0.5 \mathrm{wt} \%$ ) and $\mathrm{Cd}(\sim 0.2 \mathrm{wt} \%)$ (ESM Table 2 ). Galena is relatively pure but can locally contain sulfosalt inclusions (Fig. 6c), which belong to the tetrahedrite-tennantite series, but are much closer to tetrahedrite composition (ESM Table 3). Their average calculated formula is $\mathrm{Cu}_{9.6} \mathrm{Ag}_{0.2} \mathrm{Fe}_{0.5} \mathrm{Zn}_{2.3}\left(\mathrm{Sb}_{3.8} \mathrm{As}_{0.2}\right) \mathrm{S}_{13}$. The mean $\mathrm{Ag}$ content in most sulfosalts is around $1.18 \mathrm{wt} \%$. Bournonite with
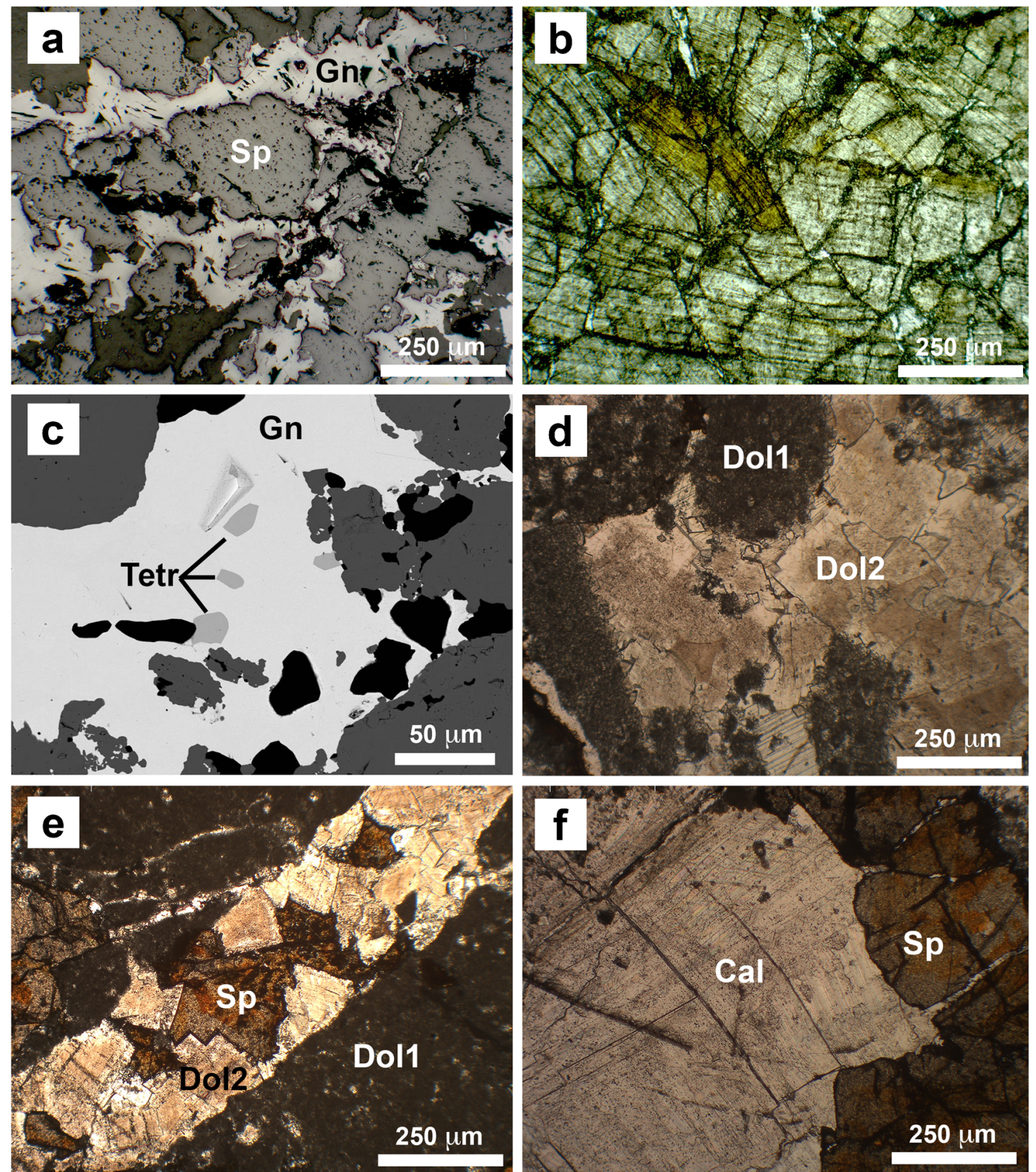

Fig. 6 Sulfide mineralization. a Association of sphalerite and finegrained galena in veinlets (optical microscopy, reflected light, NII). b Pian Bracca-Parina W level (1040 m a.s.1.): deformed sphalerite in sigmoidal structures (optical microscopy, transmitted light, $\mathrm{N}+$ ). c Tetrahedrite inclusions in galena (BSE). d, e Early dolomite (Dol1)

replacing the original limestone and macrocrystalline dolomite in veins (Dol2) (optical microscopy, transmitted light, NII). f Deformed coarse calcite crystal (optical microscopy, transmitted light, NII). Cal = calcite, Dol1 $=$ early dolomite, Dol $2=$ macrocrystalline dolomite, $\mathrm{Gn}=$ galena , $\mathrm{Sp}=$ sphalerite, Tetr $=$ tetrahedrite 
an average formula $\mathrm{Cu}_{0.98} \mathrm{Zn}_{0.05} \mathrm{Fe}_{0.01} \mathrm{~Pb}_{1.1}\left(\mathrm{Sb}_{0.95} \mathrm{As}_{0.05}\right) \mathrm{S}_{3}$ (ESM Table 4) has been observed locally. Minor pyrite and chalcopyrite are also part of the sulfide assemblage, together with covellite, which coats chalcopyrite and locally also sulfosaltsbearing galena.

In the Mt. Arera samples, we detected at least two dolomite generations among the gangue minerals, both paragenetically preexisting to sulfides (Fig. 6d, e): the first generation occurs as small crystals replacing the original limestone (Fig. 6d), while the second forms macrocrystals in veins, with textures reminiscent of "saddle" dolomite (Fig. 6e) (Radke and Mathis 1980). This second dolomite generation is characterized by average contents of about $2 \mathrm{wt} \% \mathrm{FeO}$ and $1 \mathrm{wt} \% \mathrm{MnO}$. Macrocrystalline calcite occurs in veins in several generations, which both precede and follow the sulfides in the paragenesis, but are always later than dolomite. Calcite and dolomite veins host the sulfides within voids and geodes. When occurring in the fault breccia, the coarse calcite crystals are commonly distorted (Fig. 6f).

The nonsulfides sampled for this study are from the Ponente (1070 m a.s.l.) and Piazzole (990 m a.s.l.) levels, where they occur in high-grade pockets in the CMB Formation and in the Breno Formation limestone, commonly in fault breccias. Nonsulfides are very rare in the black shales overlying the CMB Formation. Two different types of nonsulfides are recognized either as direct replacement of sulfide minerals, as well as of the host rock, or as concretions filling cavities and voids. Sulfide remnants (minor sphalerite and abundant galena) are commonly observed within the nonsulfide agglomerates, together with the unaltered carbonate gangue (calcite and dolomite). In contrast to sulfide ores and their carbonate gangue, which are locally tectonically deformed, nonsulfide minerals show no deformation, neither on the macroscopic nor on the microscopic scale. The nonsulfide minerals consist essentially of smithsonite, hemimorphite, hydrozincite, cerussite, and minor anglesite.

In the Ponente level (1070 m a.s.l.) nonsulfides often contain hemimorphite as flat, tabular crystals or as radial aggregates, near aggregates of a first cerussite generation (cerussite 1). Massive smithsonite (generation 1), together with minor hemimorphite, and with abundant gypsum replaces massive sphalerite (Fig. 7a). Gypsum occurs both as void filling and in veins (Fig. 7b). Zn-bearing illite (representative compositions are shown in ESM Table 5) has been observed as well. This illite has average $\mathrm{ZnO}$ and $\mathrm{FeO}$ contents of about 1.2 and $0.9 \mathrm{wt} \%$, respectively, with a resulting formula of $\mathrm{K}_{0.85}\left(\mathrm{Al}_{1.6}\right.$ $\left.\mathrm{Mg}_{0.3} \mathrm{Fe}_{0.07} \mathrm{Ti}_{0.02} \mathrm{Zn}_{0.06}\right)_{2}\left(\mathrm{Si}_{3.4} \mathrm{Al}_{0.6}\right)_{4} \mathrm{O}_{10}(\mathrm{OH})_{2}$. The $\mathrm{Zn}-$ bearing illite may contain inclusions of Fe-(hydr)oxide pseudomorphs after pyrite (Fig. 7c), characterized by average $\mathrm{ZnO}$ and $\mathrm{PbO}$ contents of both about $6.8 \mathrm{wt} \%$, and a $\mathrm{SiO}_{2}$ content of about $2.5 \mathrm{wt} \%$. Analyses on micaceous material in nonoxidized sulfide-bearing samples revealed that mica is here only represented by the illite-type, with a calculated formula around $\mathrm{K}_{0.9}\left(\mathrm{Al}_{1.6} \mathrm{Mg}_{0.4}\right)_{2}\left(\mathrm{Al}_{0.5} \mathrm{Si}_{3.4}\right)_{4} \mathrm{O}_{10}(\mathrm{OH})_{2}$. Oxidized samples from the Forcella level (940 $\mathrm{m}$ a.s.l.) have mineralogical features very similar to the samples of the Ponente level.

In the Piazzole level (990 $\mathrm{m}$ a.s.l.), the nonsulfide minerals replace both primary sulfides and the limestone host rock. Two generations of smithsonite can be observed. Generation 1 (as in the Ponente level) is quite massive, whereas generation 2 occurs as rice-shaped crystals growing in cavities and fractures (Fig. 7d, e). Smithsonite displays a quite constant chemical composition, with $\mathrm{FeO}$ and $\mathrm{CdO}$ contents below $1 \mathrm{wt} \%$ (ESM Table 6). Cerussite also occurs in two generations: cerussite 1 together with anglesite directly replaces galena, and cerussite 2 consists of prismatic crystals in cavities (Fig. 7f). Concretionary aggregates of needle-shaped hydrozincite crystals (hydrozincite 1 ) locally replace smithsonite 1 . The second hydrozincite generation (2) occurs as globular crusts in cavities. Hydrozincite 2 is followed by flat, tabular hemimorphite crystals, also precipitated in voids; it is associated with rounded aggregates of prismatic and tabular crystals of cerussite 2 . Hydrozincite 1 is needle-shaped, while hydrozincite 2 forms coatings on smithsonite 2 . Undeformed botryoidal calcite crusts follow the nonsulfide mineralization and commonly occur as the last precipitate on cavity walls. Zn-bearing illite has been detected also in the Ponente level.

The samples collected on the Mt. Arera also contain nonsulfide minerals. The main nonsulfide phases observed here consist of hemimorphite and of needle-shaped hydrozincite 1, associated with $\mathrm{Zn}$-bearing illite and minor smithsonite.

Figure 8 depicts the paragenesis as determined by petrographic observation on the sulfide and nonsulfide ores.

\section{Major- and minor-element geochemistry}

Chemical analyses were conducted on mineralized samples (sulfides, nonsulfides, and mixed sulfide-nonsulfide samples), characterized by $\mathrm{Zn}$ and $\mathrm{Pb}$ contents in most cases higher than $10 \mathrm{wt} \%$ (ESM Table 7). For $\mathrm{Zn}, \mathrm{Pb}$, and $\mathrm{S}$, the concentration was only evaluated as "total elemental concentration"; thus, their fractions bonded to oxygen in oxidized species were recalculated on stoichiometric basis, considering the bulk mineralogical composition of the samples.

Zinc and $\mathrm{Pb}$ concentrations are similar in the sulfide and nonsulfide samples and allow evaluating the loss or gain of trace elements in the nonsulfides. Sulfides are on average distinctly richer in $\mathrm{Ag}, \mathrm{Sb}, \mathrm{Cu}$, and $\mathrm{Ba}$ with respect to nonsulfides. However, in a few nonsulfide samples, Ag is still quite high (> 200 ppm) (ESM Table 7). Sulfides and nonsulfides are comparable in their $\mathrm{Mo}$, As, and $\mathrm{Cd}$ concentrations, but few nonsulfide samples have exceptionally higher amounts of these elements compared to sulfides. On the contrary, nonsulfides have Ga and Mn concentrations consistently higher than the precursor sulfides. In the sulfide-rich samples, a positive linear relationship is observed between the concentrations of the $\mathrm{Pb}-\mathrm{Ag}$ and $\mathrm{Zn}-\mathrm{Ge}$ pairs, whilst the amounts of the same elements are poorly 

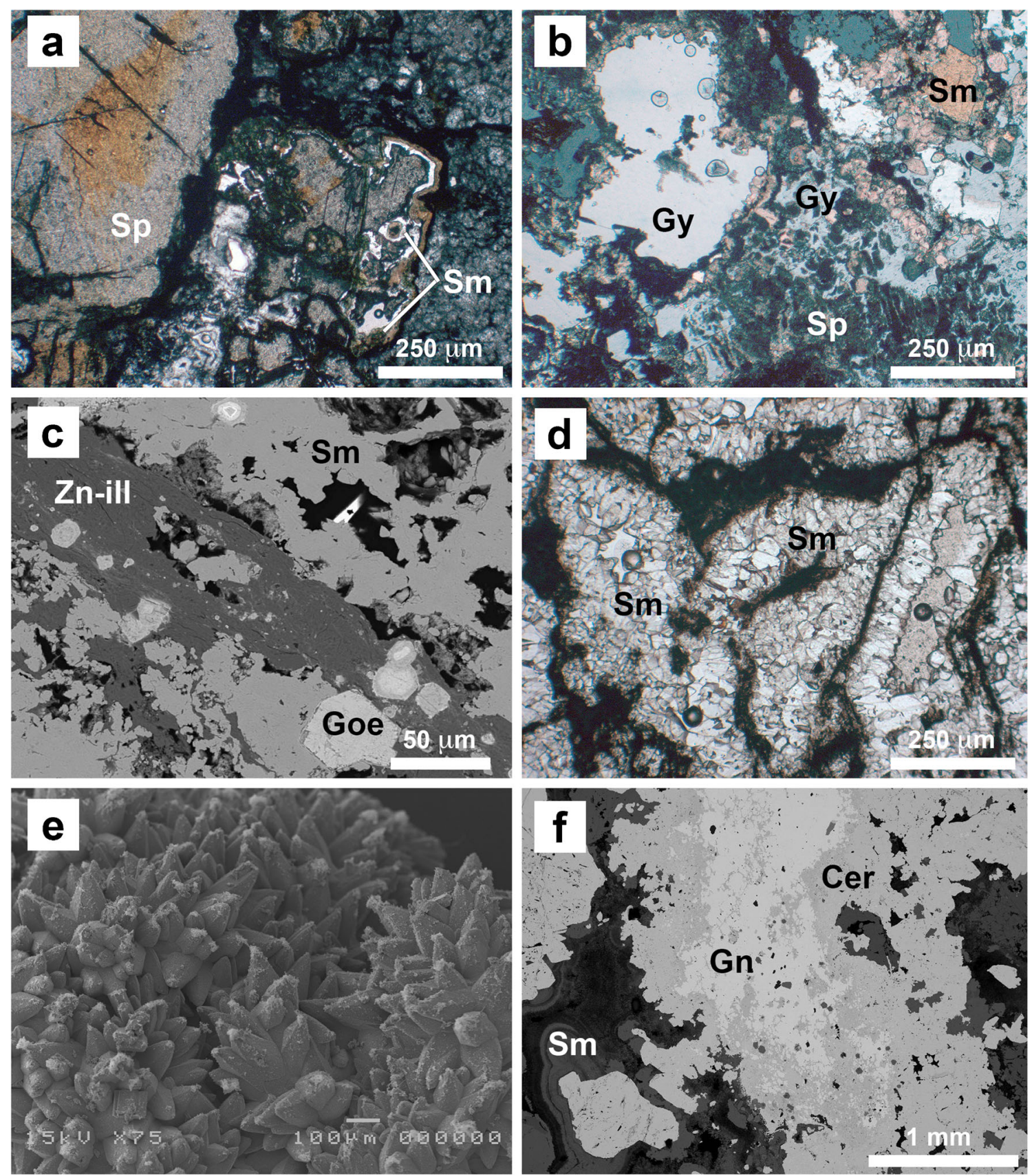

Fig. 7 Nonsulfide mineralization. a Smithsonite 1 directly replacing sphalerite (optical microscopy, transmitted light, NII). b Gypsum filling voids between smithsonite, and in part replacing sphalerite (optical microscopy, transmitted light, $\mathrm{N}+$ ). c Zn-bearing illite containing inclusions of Fe-(hydr)oxide pseudomorphs after pyrite (BSE). d Rice-shaped

crystals of smithsonite 2 growing in cavities and fractures (optical microscopy, transmitted light, NII). e Rice-shaped crystals of smithsonite 2 growing in cavities and fractures (SEM). $\mathbf{f}$ Cerussite replacing a galena vein $(\mathrm{BSE}) . \mathrm{Cer}=$ cerussite, $\mathrm{Gn}=$ galena, Goe = goethite, Gy = gypsum, $\mathrm{Sm}=$ smithsonite, $\mathrm{Sp}=$ sphalerite, $\mathrm{Zn}$-ill $=\mathrm{Zn}$-bearing illite

correlated in the nonsulfide samples (Fig. 9). All other measured trace elements do not reach significant concentrations.

\section{Carbon and oxygen isotope geochemistry}

Carbon and oxygen isotope analyses were carried out on metal-bearing carbonates from the nonsulfide orebodies, and on several calcite generations from both the sulfide gangue and in the nonsulfide assemblage throughout the Gorno area (ESM Table 8, Fig. 10). Calcite samples were collected from (1) macrocrystalline (coarse) calcite veins associated with both sulfide (hosted in limestones and black shales) and nonsulfide ores, (2) calcite crusts and concretions solely associated with $\mathrm{Zn}-\mathrm{Pb}$ nonsulfides, and (3) a few representative host rock carbonates of the Breno Formation. 
Fig. 8 Mineral paragenesis of $\mathrm{Zn}$ $\mathrm{Pb}$ mineralization in the Gorno area

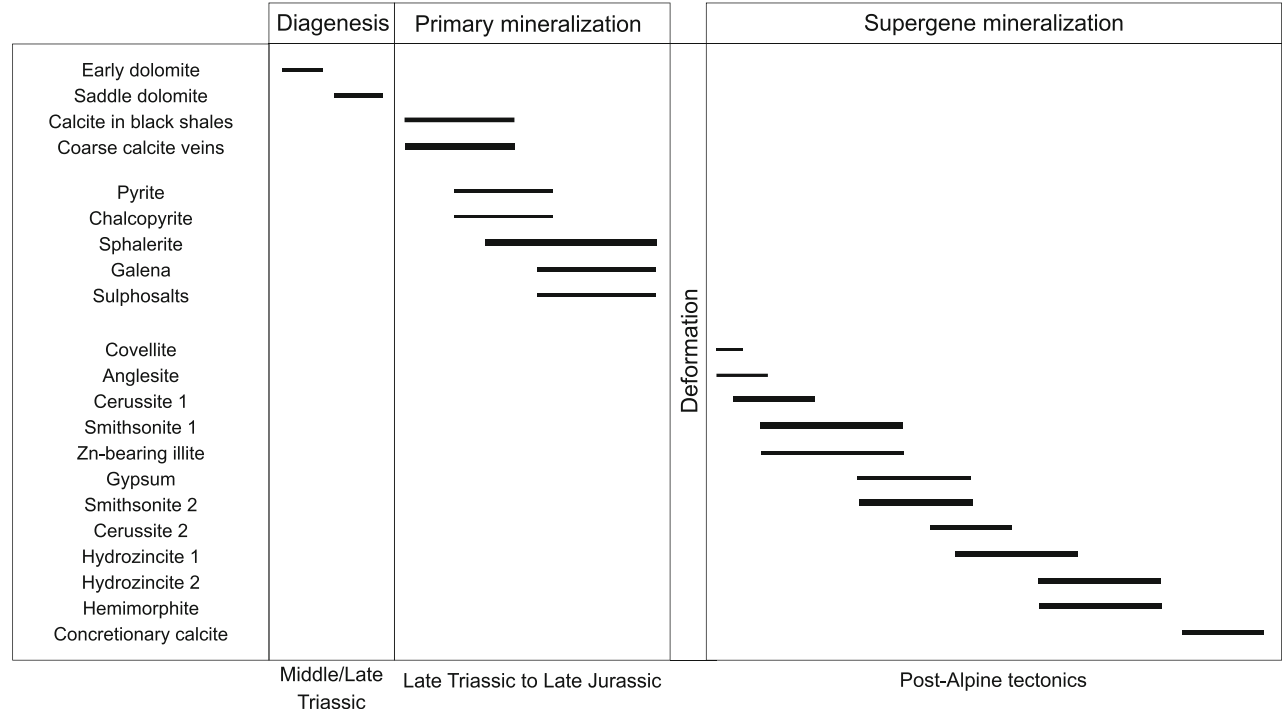

The host rock carbonates were sampled at Mt. Arera, and in the Piazzole and Forcella levels of the Val Vedra mine. Their $\delta^{13} \mathrm{C}$ composition is $1.7 \pm 0.6 \%$ V-PDB, while $\delta^{18} \mathrm{O}$ ranges from 18.8 to $23.9 \%$ V-SMOW. The calcite veins in the Breno Formation limestones are characterized by slightly lower $\delta^{13} \mathrm{C}$ (1.0 to $1.3 \%$ V-PDB) and by lower $\delta^{18} \mathrm{O}$ values (17.7 to $20.3 \%$ o V-SMOW). Macrocrystalline calcite veins, occurring within nonsulfide pockets in the Piazzole level, display $\delta^{13} \mathrm{C}$ and $\delta^{18} \mathrm{O}$ values varying between 1.0 and $1.4 \%$ V-PDB and 19.5 and $21.3 \%$ o-SMOW, respectively. These values are similar to those measured on the macrocrystalline calcites associated with the carbonate-hosted sulfide ores, which display average $\delta^{13} \mathrm{C}$ values of $1.7 \pm 0.1 \%$ V-PDB and $\delta^{18} \mathrm{O}$ of $19.1 \pm 0.6 \%$ V-SMOW. In comparison to these macrocrystalline calcites, coarse calcite in veins associated with black shale-hosted sulfides shows lower $\delta^{13} \mathrm{C}$ values $(0.1 \pm 0.2 \%$ V-PDB $)$ but similar $\delta^{18} \mathrm{O}$ values $(20.1 \pm 1.8 \%$ o V-SMOW) (Fig. 10). The concretionary calcite paragenetically following the nonsulfide minerals is characterized by $\delta^{13} \mathrm{C}$ values between -2.2 and $-1.2 \%$ V-PDB and $\delta^{18} \mathrm{O}$ values between 24.7 and $25.0 \%$ V-SMOW.
The supergene $\mathrm{Zn}$ carbonates, mostly sampled in the Piazzole and Ponente levels, show a wide range in the isotope ratios, with $\delta^{13} \mathrm{C}$ ranging from -6.0 to $1.7 \%$ VPDB and $\delta^{18} \mathrm{O}$ between 21.9 and $26.8 \%$ V-SMOW (Fig. 10). The carbon and oxygen isotope ratios of most smithsonite samples $\left(\delta^{13} \mathrm{C}=-3.1\right.$ to $1.7 \%$ V-PDB; $\delta^{18} \mathrm{O}=$ 24.1 to $26.8 \%$ V-SMOW) are higher than the values of the hydrozincite samples $\left(\delta^{13} \mathrm{C}=-6.0\right.$ to $0 \%$ V-PDB; $\delta^{18} \mathrm{O}=$ 21.9 to $23.9 \%$ V-SMOW). Smithsonite 1 is characterized by $\delta^{13} \mathrm{C}$ values between -2.8 and $1.7 \%$ V-PDB and $\delta^{18} \mathrm{O}$ values between 24.1 and $26.8 \%$ V-SMOW, similar to the isotope ratios of smithsonite $2\left(\delta^{13} \mathrm{C}=-3.14\right.$ to $0.1 \%$ VPDB; $\delta^{18} \mathrm{O}=24.4$ and $25.5 \%$ V-SMOW). Hydrozincite 1 shows $\delta^{13} \mathrm{C}$ and $\delta^{18} \mathrm{O}$ values of -2.9 to $0.5 \%$ V-PDB and 21.8 to $25.8 \%$ V-SMOW, respectively, on average higher than hydrozincite $2\left(\delta^{13} \mathrm{C}=-6.2\right.$ to $-3.9 \%$ VPDB; $\delta^{18} \mathrm{O}=21.8$ to $23.5 \%$ V-SMOW). Smithsonite and hydrozincite isotope ratios depict a positive linear array (Fig. 10) from positive $\delta^{13} \mathrm{C}$ and high $\delta^{18} \mathrm{O}$ values toward negative $\delta^{13} \mathrm{C}$ and lower $\delta^{18} \mathrm{O}$ values.
Fig. 9 Bulk chemical analyses on sulfide, nonsulfide, and mixed mineralized samples. $\mathrm{Zn}$ vs. Ge and $\mathrm{Pb}$ vs. $\mathrm{Ag}$ biplots

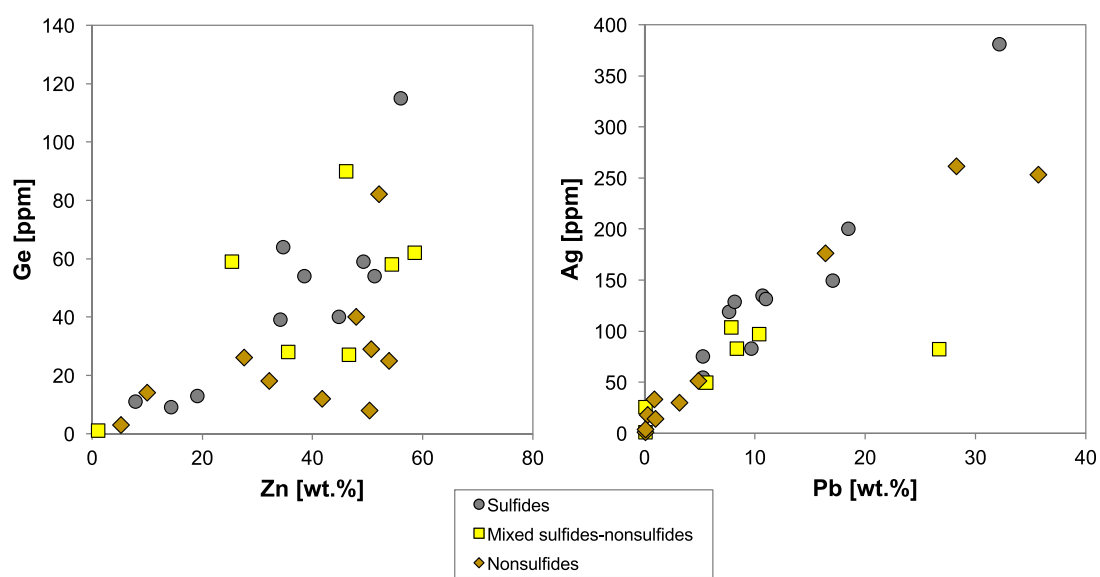


Fig. 10 Carbon and oxygen isotope composition of carbonates from the Gorno $\mathrm{Zn}$ project

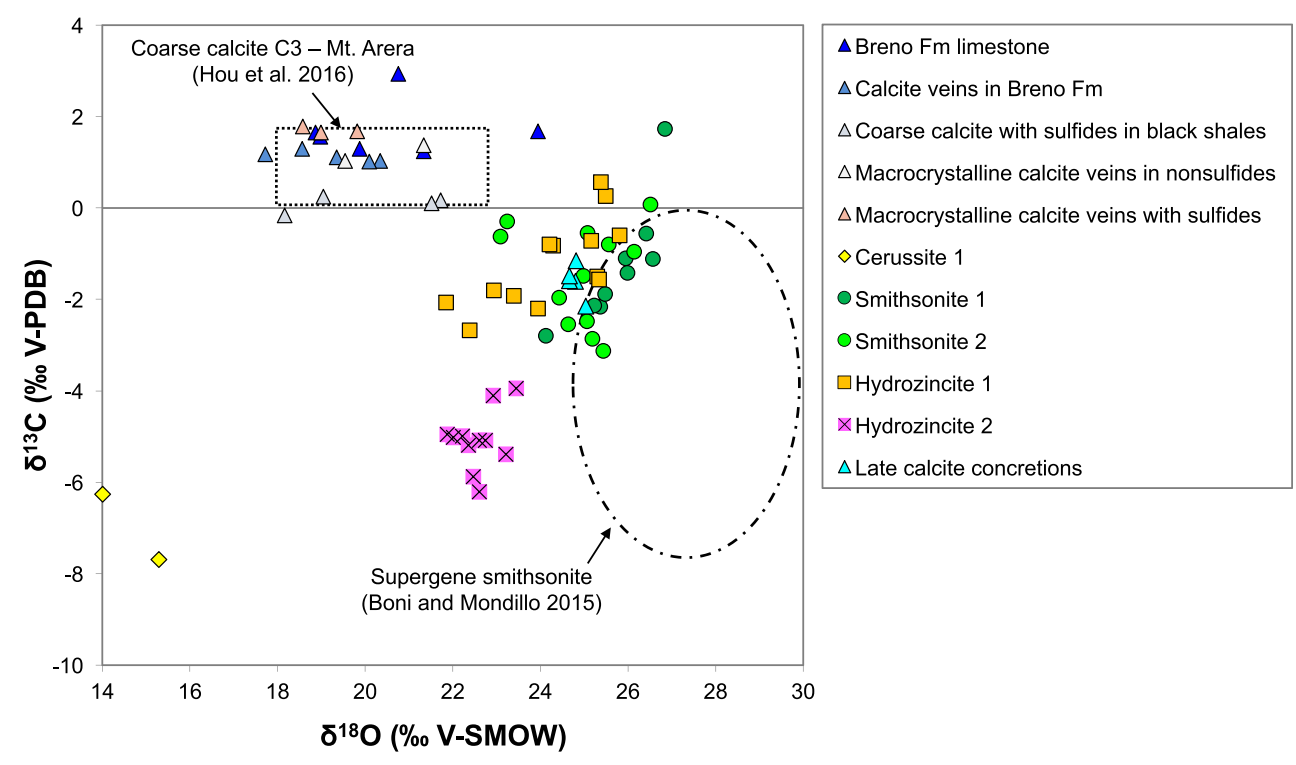

Two samples of cerussite 1 have $\delta^{13} \mathrm{C}$ values of -6.3 and $7.7 \% 0 \mathrm{~V}-\mathrm{PDB}$, and $\delta^{18} \mathrm{O}$ of 14.0 and $15.3 \% \mathrm{~V}-\mathrm{SMOW}$. Cerussite 2 could not be analyzed.

\section{Discussion}

\section{New inferences on the sulfide mineralization in the Gorno Zn project}

The mineralogical assemblage of the Gorno $\mathrm{Zn}$ project documented in this study partly agrees with the data from previous investigations (e.g., Omenetto 1966; Rodeghiero and Vailati 1978). However, the identification of dolomite and calcite generations preexisting to sulfides, and the detection of a distinct Alpine deformation affecting the sulfide assemblage, which is missing in the nonsulfide ores, shed new light on the genesis of both the sulfides and the nonsulfides. At first sight, these simple textural relationships suggest that the emplacement of the sulfide mineralization in the Gorno area took place before the Alpine orogeny, in analogy to other similar deposits occurring in the Eastern and Southern Alps (Zeeh et al. 1998; Leach et al. 2003), whereas the formation of the clearly undeformed nonsulfides must have occurred after the main orogenic phases. Several authors (e.g., Ehrendreich 1960; Vaché 1962; Di Cobertaldo and Comisso 1964) suggested that the sulfide mineralization in the Gorno area was of synsedimentary origin, whereas other authors (Zucchetti 1960; Omenetto 1966; Vailati 1966; Rodeghiero and Vailati 1978) considered the sulfides being epigenetic. Our petrographic studies have shown that the sulfides follow in the paragenesis the emplacement of $\mathrm{Mn}-\mathrm{Fe}$-bearing saddle dolomite and macrocrystalline (coarse) calcite. This relationship was observed both in the samples collected in the Breno
Formation limestone, as in the samples derived from the black shales at the contact between the CMB Formation and the "basal tongue" of the Gorno Formation. A similar dolomitecalcite association had been already mentioned in a recent study on the dolomitization of the Breno Formation (Hou et al. 2016), in which the Mt. Arera area was investigated as well. Hou et al. (2016) described several dolomite and calcite generations, from the earliest to the latest: dolomicrite (D1), equant replacive dolomite (D2), and large fracture-filling Fe-Mn-bearing saddle dolomite (D3). The latter saddle dolomite is associated with coarse calcite $\mathrm{C} 3$, crosscutting the earlier calcite and dolomite generations. The D3 and C3 generations are very similar to those we observed in the sulfide-rich samples of the Val Vedra mine. This textural similarity is also reflected in the carbon and oxygen isotopic composition of the carbonates (Fig. 10): the C3 calcite analyzed by Hou et al. (2016) has similar $\delta^{13} \mathrm{C}$ and $\delta^{18} \mathrm{O}$ values (avg. $\delta^{13} \mathrm{C}=0.7 \%$ V-PDB; avg. $\delta^{18} \mathrm{O}=21 \%$ o V-SMOW) as the coarse calcite associated with the sulfides in the Breno Formation (avg. $\delta^{13} \mathrm{C}=1.6 \%$ V-PDB; avg. $\delta^{18} \mathrm{O}=19.1 \%$ o $\mathrm{V}$-SMOW), with that in the weathered sulfides of the Breno Formation (avg. $\delta^{13} \mathrm{C}=1.2 \%$ V-PDB; avg. $\delta^{18} \mathrm{O}=20.4 \%$ o-SMOW), and with the calcite gangue of the sulfides in the black shales (avg. $\delta^{13} \mathrm{C}=0.1 \%$ V-PDB; avg. $\delta{ }^{18} \mathrm{O}=20.1 \%$ V-SMOW). After Hou et al. (2016), the C3 calcite and D3 dolomite were precipitated from hot basinal fluids that circulated and interacted with volcanoclastites and other sediments of the Lombardian basin, during late diagenetic stages in deep burial settings. The high homogenization temperature (avg. $\mathrm{T}_{\mathrm{h}}=120{ }^{\circ} \mathrm{C}$ ) and salinity ( 22 eq. wt $\% \mathrm{NaCl}$ ) estimated for the fluids precipitating $\mathrm{C} 3$ and $\mathrm{D} 3$, along with the oxygen isotope ratios, support an origin from hot, possibly basinal fluids (Hou et al. 2016). If the saddle dolomite and coarse calcite occurring in the gangue of the sulfides from the Val Vedra mine (which have the same textural-petrographic 
relationships, and the same $\delta^{18} \mathrm{O}$ compositions of the carbonates mentioned by Hou et al. 2016) were precipitated from similar fluids, the sulfides that paragenetically follow the carbonates would be of epigenetic origin. The high $\mathrm{Cu}, \mathrm{Sb}, \mathrm{As}$, $\mathrm{Ag}, \mathrm{Mo}, \mathrm{Ge}$, and $\mathrm{Cd}$ concentrations in the sulfide assemblage are also in agreement with hydrothermal fluid circulation through volcaniclastic sediments.

A similar "saddle" dolomite-coarse sparry calcite pair has been described from the Bleiberg deposit in Austria by Zeeh et al. (1998). At Bleiberg, the sulfide minerals were deposited after a first generation of saddle dolomite and were followed by coarse sparry calcite, at temperatures never exceeding $100-110^{\circ} \mathrm{C}$ (Henjes-Kunst et al. 2017). The stable isotope values of these carbonates (coarse calcite: $\delta^{13} \mathrm{C} \sim 2 \%$ V V-PDB and $\delta^{18} \mathrm{O}$ between 21 and $24 \% 0 \mathrm{~V}-\mathrm{SMOW}$; saddle dolomite: $\delta^{13} \mathrm{C} \sim 2.7 \% \circ \mathrm{V}$ PDB and $\delta^{18} \mathrm{O}$ between 20 and 25\%o V-SMOW) are roughly similar to the isotope ratios of the analogous carbonates measured in this study and to those measured by Hou et al. (2016).

\section{Nonsulfide genesis, nature of the fluids, and relationships with climate evolution}

Regarding the nonsulfide mineralization stage, we identified several smithsonite, hydrozincite, and hemimorphite generations directly replacing sphalerite, or occurring as concretions filling voids and cavities, and cerussite replacing galena, with textural features typical of supergene ores (Boni and Mondillo 2015). Gypsum was locally detected as gangue of nonsulfide ores. Concretionary calcite was precipitated after all the mentioned phases, occurring in the nonsulfide mineralization as final cavity-filling precipitate. From a genetic point of view, it is relevant that the oxidized $\mathrm{Zn}$ and $\mathrm{Pb}$ minerals mainly formed at direct expense of the sulfides, with a very small amount of nonsulfide ores showing wall-rock replacement features, e.g., Zn-bearing illite that likely formed by progressive "zincitization" of a preexisting Zn-barren illite (see for example Mondillo et al. 2014). These facts suggest that the $\mathrm{Zn}-\mathrm{Pb}$-bearing solutions deriving from sulfide alteration were quickly neutralized by the carbonate environment, and did not migrate for long distances through the fractures of the host rock. This is reflected by the geochemistry of the nonsulfides, which are characterized by concentrations of immobile elements (e.g., Mo, As, Cd, Ga, and Mn) similar or higher than the parental sulfides, suggesting that $\mathrm{Zn}$ was not leached from its original source. Such circulation is further confirmed by the co-occurrence of gypsum, whose formation generally takes place in supergene environments with limited fluid migration (Reichert and Borg 2008) according to the following reaction:

$\mathrm{ZnS}$ (sphalerite) $+\mathrm{CaCO}_{3}$ (calcite) $+2 \mathrm{H}_{2} \mathrm{O}+2 \mathrm{O}_{2} \rightarrow$

$\rightarrow \mathrm{ZnCO}_{3}$ (smithsonite) $+\mathrm{CaSO}_{4} \cdot 2 \mathrm{H}_{2} \mathrm{O}$ (gypsum).
At the same time, the presence of hydrozincite at great depth in the Piazzole level (990 m a.s.l.) indicates that hydrozincite-precipitating aqueous solutions were in equilibrium with the atmosphere (undersaturated zone), since hydrozincite is stable at $p \mathrm{CO}_{2(\mathrm{~g})}$ levels occurring in nearsurface settings and thus lower than those allowing smithsonite precipitation (log $\mathrm{P}_{\mathrm{CO} 2(\mathrm{~g})} \geq 0.4 \mathrm{kPa}$ at $298.2 \mathrm{~K}$; Takahashi 1960). This is only possible if aqueous solutions were in contact with air, e.g., they percolated through the carbonate rocks via open fractures. For this reason, hydrozincite precipitation must have occurred in relatively recent times, when the carbonate successions were already relatively uplifted.

The variation in the $\delta^{13} \mathrm{C}$ and $\delta^{18} \mathrm{O}$ values of the $\mathrm{Zn}$ carbonates allows further characterizing the fluids involved in the secondary mineralization processes. The $\delta^{13} \mathrm{C}$ and $\delta^{18} \mathrm{O}$ values of both smithsonite and hydrozincite show a positive correlation $\left(y=1.15 x-30.9, R^{2}=0.55\right.$ for smithsonite; $y=1.43 x-$ $36.8, R^{2}=0.73$ for hydrozincite). In particular, the highest $\delta^{13} \mathrm{C}$ and $\delta^{18} \mathrm{O}$ values were measured in the earlier generations of smithsonite and hydrozincite, whereas the lowest values are recorded in the late hydrozincite generations. This pattern suggests that the $\mathrm{Zn}$ carbonates formed from several distinct fluids of meteoric origin, which became progressively depleted in ${ }^{18} \mathrm{O}$ and ${ }^{13} \mathrm{C}$ during the oxidation of the sulfides and the precipitation of nonsulfide minerals. The positive $\delta^{13} \mathrm{C}$ values of the earliest smithsonite likely represent an initially higher contribution of carbon from the carbonate host rock. The $\delta^{18} \mathrm{O}$ values (24.5 to $26.8 \%$ V-SMOW) of these early phases are in equilibrium with fluids of supergene origin, as well as with temperatures ( $T=15$ $25^{\circ} \mathrm{C}$ ) assumed for the precipitation of most nonsulfide deposits of the world (Gilg et al. 2008). For comparison, smithsonite in the Bleiberg mine has isotopic values of $\delta^{13} \mathrm{C}$ between -5.5 and $-4 \%$ V-PDB and $\delta^{18} \mathrm{O}$ between 24.7 and $26.8 \%$ V-SMOW (Kuhlemann 1995). The same origin is suggested by the isotopic compositions of the Gorno cerussite $\left(\delta^{13} \mathrm{C}=-6.3\right.$ and $-7.7 \%$ o V-PDB; $\delta^{18} \mathrm{O}=14.0$ and $15.3 \%$ V-SMOW). If we assume that paragenetically associated smithsonite 1 and cerussite 1 precipitated at the same time, from a single fluid, using the measured smithsonite and cerussite $\delta^{18} \mathrm{O}$ compositions, we can mathematically determine $\delta^{18} \mathrm{O}$ and $\mathrm{T}$ of the precipitating fluid. This is possible by using a system defined by the mineral-water fractionation equations of cerussite (1; Gilg et al. 2008) and smithsonite (2; Füger et al. 2018):

$$
\begin{aligned}
& 1000 \ln \alpha_{\text {cerussite-water }}=2.29\left(10^{6} / T^{2}\right)-3.56 \\
& 1000 \ln \alpha_{\text {smithsonite-water }}=3.21\left(10^{6} / T^{2}\right)-3.63
\end{aligned}
$$

( $T$ given in Kelvin). Taking an average smithsonite and cerussite $\delta^{18} \mathrm{O}$ of 25.6 and $14.7 \%$ o, respectively, a fluid $\delta^{18} \mathrm{O}$ of $-8.6 \%$ and a temperature of about $19^{\circ} \mathrm{C}$ are calculated for the early nonsulfide phases. Interestingly, the calculated $\delta^{18} \mathrm{O}$ 
composition and temperature of the fluids precipitating the supergene Gorno carbonates are similar to those of meteoric waters $\left(\delta^{18} \mathrm{O}=-9.9\right.$ to $-8.9 \%$, $T=16$ to $\left.21^{\circ} \mathrm{C}\right)$ that precipitated the pedogenic carbonate nodules in the BurdigalianLanghian paleosols in the Northern Alps (Campani et al. 2012). Moreover, the calculated temperature is coherent with already existing paleontological and paleobotanical data, which indicate that the Miocene climate was warmer than today (e.g., Böhme 2003).

Late hydrozincite displays lower $\delta^{13} \mathrm{C}$, thus indicating a stronger contribution of carbon from organic matter. The contribution of organic matter in supergene $\mathrm{Zn}$ carbonates is commonly explained through progressive development of an organicrich soil interval along the path crossed by the meteoric waters before reaching the final site of mineral precipitation (Gilg et al. 2008). Considering that the study area in the Southern Alps was affected by high erosion rates in the Burdigalian, and by low erosion rates in the following periods (Reverman et al. 2012; Zanchetta et al. 2015), it was likely the development of organicrich soils. Another potential source of isotopically light carbon could be the organic carbon-rich black shales.

The decrease in $\delta^{18} \mathrm{O}$ from the early to late $\mathrm{Zn}$-carbonate generations can be related either to a fluid becoming depleted in ${ }^{18} \mathrm{O}$, or to an increase in ambient temperature. If this trend is explained by an increase in precipitation temperature, a difference of $+20^{\circ} \mathrm{C}$ should have occurred between the early and late $\mathrm{Zn}$ carbonates. Such a significant temperature lapse would indicate the transition from a supergene to a hydrothermal carbonate system (see for example the Angouran deposit, Iran; Boni et al. 2007): neither of the characteristics of such a system has been observed in the paragenesis of the Gorno mineralization. Climate variations could have also influenced the nature of the supergene ore-forming fluids. The Miocene climate was globally warmer than today (e.g., Böhme 2003), with low amplitude seasonal temperature variations in a subtropical context also comprising seasonal dryness (Suc et al. 2018). In general, the climate became slightly cooler since the mid-Miocene (13.6 Ma) to early Pliocene, when a subtle warmer phase developed (Jiménez-Moreno et al. 2008). From the mid-Pliocene (3.3 Ma) to Pleistocene, colder and more variable conditions prevailed (Suc et al. 2018). Even though these global trends cannot be directly transferred to the regional record of the southern Alpine domain, there is no evidence of other significant climatic changes between mid-Miocene and late Pliocene in the study region (Willett 2010). Considering that the Gorno area was affected by an exhumation pulse in the Burdigalian, and that exhumation likely continued at lower rates until the Pliocene (Reverman et al. 2012), it is possible that sulfide weathering lasted for this entire period (Burdigalian-Pliocene), being affected by seasonal variations under a subtropical regime, with a cooling trend until the slightly warmer early Pliocene peak. These climatic conditions cannot justify significantly higher temperatures during precipitation of $\mathrm{Zn}$-carbonates. The lower $\delta^{18} \mathrm{O}$ values of the late $\mathrm{Zn}$ carbonate generations are thus more likely due to a ${ }^{18} \mathrm{O}$ depletion of the mineral-precipitating waters. In the studied area, this may be explained by progressive groundwater recharge from higher altitudes, since precipitation at higher elevation is depleted in ${ }^{18} \mathrm{O}$. Because of this depletion process, precipitation in Alpine regions can have $\delta^{18} \mathrm{O}$ values of down to $-22 \%$ V V-SMOW (Liebminger et al. 2006; Longinelli et al. 2006; Field 2010). If true, a progressive recharge of meteoric waters sourced from higher elevations could be related to the progressive exhumation of the Gorno orebodies during the precipitation of the nonsulfides.

\section{Genesis of the Gorno ores}

The results of this study suggest that the pre-Alpine sulfide emplacement could have been related to the generation and circulation of hot brines in deep burial settings, triggered by enhanced heat flow during the Mesozoic extension in the Southern Alps, either during Early Jurassic rifting or thermal subsidence, which started in Middle Jurassic (Berra and Carminati 2010). This age interval can be considered in analogy to other similar deposits of the Eastern and Southern Alps, such as Raibl (Brigo and Cerrato 1994; Doglioni 1988) and Bleiberg. Bleiberg's main stage of ore formation has been dated at Early Jurassic by Zeeh et al. (1998) with petrographic methods, and with absolute dating at ca. $200 \mathrm{Ma}$ by Melcher et al. (2010), Henjes-Kunst (2014), and Henjes-Kunst et al. (2017). The mineralizing hydrothermal fluids probably circulated upward through the Mesozoic normal faults with the sulfides being precipitated in correspondence to the black shale intervals of the Triassic platform carbonates, at the contact between the CMB and the "basal tongue" of the Gorno Formation. The shales may have acted as seals for the migration of the metal-bearing brines, thus allowing not only for the precipitation of the ores in the mentioned stratigraphic interval but also in stratabound dissolution-collapse breccias, as well as in fault breccias in the underlying carbonates (i.e., the $\mathrm{CMB}$ and the Breno Formations). This mechanism is in agreement with the features shown by other typical sediment-hosted $\mathrm{Zn}$ $\mathrm{Pb}$ sulfide deposits (e.g., Heijlen et al. 2003; Leach et al. 2005; Ashton et al. 2015; Ostendorf et al. 2015).

As suggested by Zanchi et al. (2012), the Triassic-Middle Jurassic tectonic lineaments, which may have controlled the deposition of the primary sulfides in the Gorno area (Vailati 1966), were reactivated by Alpine tectonics (Late CretaceousEocene). This process, together with the southward propagation of the fold-and-thrust belt during Oligocene, likely caused fracturing and brecciation of the preexisting sulfide-bearing fault zones mostly occurring in the $\mathrm{CMB}$ and Breno Formations. After Zanchetta et al. (2015), much of the exhumation of the Triassic sediments in the Gorno area occurred in the early Miocene (Burdigalian). However, for the remaining Miocene interval until Pliocene, the climate had favored 
erosion, maintaining lower exhumation rates after the cessation of major south Alpine tectonics (Reverman et al. 2012). This suggests that the weathering episodes responsible of the formation of the $\mathrm{Zn}$ nonsulfides in the Gorno area could have occurred since the Burdigalian. The exhumation of the Lower Triassic-Carnian carbonate rocks favored the deep percolation of meteoric waters toward and across the mineralized zones, the alteration of sulfides, and eventually the precipitation of secondary supergene minerals. The late hydrozincite generations were likely precipitated in the Pliocene, during the latest and low-rate exhumation stages characterized by a greater abundance of open fractures. Since the middle Pliocene, the weathering process progressively ceased, due to the onset of colder climate conditions.

A Quaternary upper limit for the timing of nonsulfide formation in our area of interest seems to be confirmed by the carbon and oxygen isotopic compositions of the concretionary calcite that paragenetically follows the deposition of all the supergene $\mathrm{Zn}$ and $\mathrm{Pb}$ minerals. In fact, this calcite has a $\delta^{18} \mathrm{O}$ composition (avg. $\delta^{13} \mathrm{C}=-1.6 \%$, avg. $\delta^{18} \mathrm{O}=24.9 \%$ ) not compatible with the coprecipitation with the nonsulfide minerals smithsonite, cerussite, and hydrozincite. However, these values are similar to the isotopic compositions of calcite (avg. $\delta^{13} \mathrm{C}=-3 \%$ o, avg. $\delta^{18} \mathrm{O}=23 \%$ ) derived from the dedolomitization of the Dolomia Principale Formation during the Quaternary (Ronchi et al. 2004).

\section{Conclusions}

The sulfide ores hosted in both limestones and black shales of the Breno and CMB Formations mainly consist of sphalerite, galena with sulfosalt inclusions, and minor pyrite and chalcopyrite. The gangue consists of dolomite, calcite and quartz. Both the primary ores and gangue are deformed. Several generations of distinctly undeformed nonsulfide minerals (i.e., smithsonite, hemimorphite, hydrozincite, and cerussite) replace the sulfides, or form crusts and concretions in dissolution cavities. These textural relationships clearly suggest that the emplacement of the sulfide mineralization occurred before the Alpine orogeny, whereas the precipitation of the nonsulfides occurred after the main deformation and uplift stages of the Alpine orogeny.

The precipitation of sulfides paragenetically follows the emplacement of Mn-Fe-bearing saddle dolomite and macrocrystalline calcite. This association, together with carbon and oxygen isotope ratios of the carbonates of $\sim 1 \%$ o VPDB and $\sim 20 \%$ o-SMOW, respectively, is compatible with precipitation from hydrothermal fluids $\left(T=100-150^{\circ} \mathrm{C}\right)$ in a deep burial setting. These characteristics suggest that sulfide emplacement occurred during the Mesozoic extension, either during the Early Jurassic rifting stage or in the drifting stage and thermal subsidence active from Middle Jurassic onwards, in analogy to other similar deposits in the Eastern and Southern Alps.

The carbon and oxygen isotope ratios of the various $\mathrm{Zn}$ carbonates show a relatively wide range, with the early generations characterized by $\delta^{18} \mathrm{O}$ values between 24.1 and $26.8 \%$ V-SMOW and $\delta^{13} \mathrm{C}$ values from -3.1 to $1.7 \%$ VPDB. The late generation of $\mathrm{Zn}$-carbonates has $\delta^{18} \mathrm{O}$ and $\delta^{13} \mathrm{C}$ values from 21.9 to $23.9 \%$ V-SMOW and -6 to $-4 \%$ o $\mathrm{V}$-PDB, respectively. These compositions, as those measured on cerussite $\left(\delta^{13} \mathrm{C}=-6.3\right.$ and $-7.7 \%$; $\delta^{18} \mathrm{O}=14.0$ and $15.3 \%$ ), agree with the formation of the nonsulfides in a supergene environment. By using the O-isotopic compositions, a precipitation temperature of $19{ }^{\circ} \mathrm{C}$ was calculated for the $\mathrm{Zn}$ and $\mathrm{Pb}$ carbonates, this suggesting that the nonsulfides formed under a climate warmer than today. The $\delta^{18} \mathrm{O}$ decrease from early to late $\mathrm{Zn}$-carbonate generations likely reflects a progressive ${ }^{18} \mathrm{O}$ depletion in the mineral-precipitating waters, possibly related to the progressive involvement of meteoric waters recharged at higher altitudes. This evolution suggests that the genesis of nonsulfides occurred during the exhumation processes affecting the Gorno area since Miocene to Pliocene.

Acknowledgments This work was carried out with the assistance of funds Ric. Dipt. 2017 and Ric. Dipt. 2018 (DiSTAR, Università degli Studi di Napoli Federico II), granted to N. Mondillo and M. Boni. Part of the analyses was funded by Alta Zinc Ltd. R. Milesi is thanked for his help in the field and during sample collection. We are grateful to the Editor-in-Chief B. Lehmann, to F. Choulet and B. Saini-Eidukat for their comments, which greatly enhanced the quality of the paper. The Associate Editor F. Melcher is thanked for handling the manuscript.

Open Access This article is distributed under the terms of the Creative Commons Attribution 4.0 International License (http:// creativecommons.org/licenses/by/4.0/), which permits unrestricted use, distribution, and reproduction in any medium, provided you give appropriate credit to the original author(s) and the source, provide a link to the Creative Commons license, and indicate if changes were made.

\section{References}

Arfè G, Mondillo N, Boni M, Balassone G, Joachimski M, Mormone A, Di Palma T (2017) The karst-hosted Mina Grande nonsulfide zinc deposit, Bongará district (Amazonas Region, Peru). Econ Geol 112: $1089-1110$

Arfè G, Mondillo N, Boni M, Joachimski M, Balassone G, Mormone A, Santoro L, Medrano EC (2018) The Cristal Zn prospect (Amazonas region, Northern Peru). Part II: an example of supergene enrichments in tropical areas. Ore Geol Rev 95:1076-1105

Ashton JH, Blakemn RJ, Geraghty JF, Beach A, Coller D, Philcox ME, Boyce AJ, Wilkinson JJ (2015) The Giant Navan carbonate-hosted $\mathrm{Zn}-\mathrm{Pb}$ deposit - a review. In: Archibald SM, Piercey SJ (eds) Current perspectives on zinc deposits, Irish Association for Economic Geology, vol 2015, pp 85-122

Assereto R, Brigo L, Brusca C, Omenetto P, Zuffardi P (1976) Italian ore/ mineral deposits related to emersion surfaces: a summary. Mineral Deposita 11:170-179 
Assereto R, Jadoul F, Omenetto P (1977) Stratigrafia e metallogenesi del settore occidentale del distretto a $\mathrm{Pb}, \mathrm{Zn}$, fluorite e barite di Gorno (Alpi Bergamasche). Riv Ital Paleont Strat 83(3):395-532

Assereto R, Brigo L, Jadoul F, Omenetto P, Perna G, Rodeghiero R, Vailati G (1978) Recent studies on Pb-Zn-fluorite and barite deposits in the Mid- and Upper-Triassic series of the Lombardic Prealps (northern Italy). Verh Geol B-A 3:197-204

Bernoulli D (2007) The pre-Alpine geodynamic evolution of the Southern Alps: a short summary. Bull Angewandte Geol 12(2):3-10

Berra F, Carminati E (2010) Subsidence history from a back stripping analysis of the Permo-Mesozoic succession of the Central Southern Alps (Northern Italy). Basin Res 22:952-975

Bertotti G, Picotti V, Bernoulli D, Castellarin A (1993) From rifting to drifting: tectonic evolution of the South-Alpine upper crust from the Triassic to the Early Cretaceous. Sedimentary Geol 86:53-76

Böhme M (2003) The Miocene Climatic Optimum: evidence from ectothermic vertebrates of Central Europe. Palaeogeogr Palaeoclimatol Palaeoecol 195:389-401

Boni M, Large D (2003) Non-sulfide zinc mineralization in Europe: an overview. Econ Geol 98:715-729

Boni M, Mondillo N (2015) The "calamines" and the "others": the great family of supergene nonsulfide zinc ores. Ore Geol Rev 67:208-233

Boni M, Gilg HA, Balassone G, Schneider J, Allen CR, Moore F (2007) Hypogene $\mathrm{Zn}$ carbonate ores in the Angouran deposit, NW Iran. Mineral Deposita 42:799-820

Brigo L, Cerrato P (1994) Distribution of Middle-Upper Triassic carbonate-hosted lead-zinc mineralization. In: Boni M, Fontbote L (eds) Sediment-hosted Zn-Pb ores. Springer, Heidelberg, pp 179197

Brigo L, Kostelka L, Omenetto P, Schneider HJ, Schroll E, Schulz O, Strucl I (1977) Comparative reflections on four alpine $\mathrm{Pb}-\mathrm{Zn}$ deposits. In: Klemm DD, Schneider HJ (eds) Time and strata-bound ore deposits. Springer-Verlag, Berlin, pp 273-293

Campani M, Mulch A, Kempf O, Schlunegger F, Mancktelow N (2012) Miocene paleotopography of the Central Alps. Earth Planet Sc Lett 337-338:174-185

D'Adda P, Zanchi A, Bergomi MA, Berra F, Malusà MG, Tunesi A, Zanchetta S (2011) Polyphase thrusting and dyke emplacement in the central southern Alps (northern Italy). I J Earth Sc 100:10951113

Di Cobertaldo D, Comisso G (1964) Il giacimento zincifero di M. Trevasco in Val Seriana. Ist Lomb Acc Sc E Lett, Rend C1 Sc (A). Milano 98:763-786

Doglioni C (1988) Note sull'evoluzione strutturale della zona di Raibl. In: Broglio Loriga C, Doglioni C, Neri C (eds) Studi stratigrafici e strutturali nell'area mineraria di Raibl, Società Italiana Miniere S.p.A 47 p

Ehrendreich H (1960) Ricerche geo-giacimentologiche a Gorno. Giornate di studio sulle ricerche geogiacimentologiche, AMMI, 22-23 Novembre 1960, Roma

Field RD (2010) Observed and modeled controls on precipitation $\delta^{18} \mathrm{O}$ over Europe: from local temperature to the northern annular mode. $\mathrm{J}$ Geoph Res 115:1-14

Füger A, Méheut M, Mavromatis V, Leis A, Dietzel M (2018) Oxygen isotope fractionation during smithsonite formation from aqueous solutions. Chem Geol 495:76-89

Gaetani M (1975) Jurassic stratigraphy of the Southern Alps: a review. In: Squyres C (ed) Geology of Italy. The Earth Sciences. Society of the Lybian Arab Republic, Tripoli, pp 377-402

Gilg HA, Struck U, Vennemann T, Boni M (2003) Phosphoric acid fractionation factors for smithsonite and cerussite between 25 and $72{ }^{\circ} \mathrm{C}$. Geochim Cosmochim Acta 67:4049-4055

Gilg HA, Boni M, Hochleitner R, Struck U (2008) Stable isotope geochemistry of carbonate minerals in supergene oxidation zones of $\mathrm{Zn}$ $\mathrm{Pb}$ deposits. Ore Geol Rev 33:117-133
Heijlen W, Muchez P, Banks DA, Schneider J, Kucha H, Keppens E (2003) Carbonate hosted $\mathrm{Zn}-\mathrm{Pb}$ deposits in Upper Silesia, Poland: origin and evolution of mineralizing fluids and constraints on genetic models. Econ Geol 98:911-932

Henjes-Kunst E (2014) The Pb-Zn deposits in the Drau Range (Eastern Alps, Austria/Slovenia): a multi-analytical research approach for investigation of the ore-forming mechanisms. PhD thesis. Montanuniversität Leoben, Leoben

Henjes-Kunst E, Raith JG, Boyce AJ (2017) Micro-scale sulfur isotope and chemical variations in sphalerite from the Bleiberg $\mathrm{Pb}-\mathrm{Zn}$ deposit, Eastern Alps, Austria. Ore Geol Rev 90:52-62

Hitzman MW, Reynolds NA, Sangster DF, Allen CR, Carman CE (2003) Classification, genesis and exploration guides for nonsulfide zinc deposits. Econ Geol 98:685-714

Hou Y, Azmy K, Berra F, Jadoul F, Blamey NJF, Gleeson SA, Brand U (2016) Origin of the Breno and Esino dolomites in the western Southern Alps (Italy): implications for a volcanic influence. Marine Petroleum Geol 69:38-52

Jadoul F, Omenetto P (1980) Diagenetic evolution of ore-bearing sediments in karst cavities: examples from the Triassic of the Bergamasc Alps (Gorno District, Northern Italy). N f J Geol Paläont 1:17-32

Jadoul F, Rossi PM (1982) Evoluzione paleogeografico-strutturale e vulcanismo triassico nella Lombardia centro-occidentale. In: Castellarin A, Vai GB (eds) Guida alla geologia del Sudalpino centro-occidentale: Guide Geologiche Regionali, SGI, pp 143-155

Jadoul F, Berra F, Frisia S (1992) Stratigraphic and paleogeographic evolution of a carbonate platform in an extensional tectonic regime: the example of the Dolomia Principale in Lombardy (Italy). Riv Ital Paleont Strat 98:29-44

Jadoul F, Berra F, Bini A, Ferliga C, Mazzoccola D, Papani L, Piccin A, Rossi R, Rossi S, Trombetta GI (2012) Note Illustrative della Carta Geologica d'Italia alla scala 1:50.000, foglio 077, Clusone $120 \mathrm{p}$

Jiménez-Moreno G, Fauquette S, Suc J-P (2008) Vegetation, climate and palaeoaltitude reconstructions of the Eastern Alps during the Miocene based on pollen records from Austria, Central Europe. J Biogeogr 35:1638-1649

Kim ST, Mucci A, Taylor BE (2007) Phosphoric acid fractionation factors for calcite and aragonite between 25 and $75^{\circ} \mathrm{C}$ : revisited. Chem Geol 246:135-146

Kuhlemann J (1995) Zur Diagenese des Karawanken-Nordstammes (Österreich/ Slowenien): spättriassische, epigenetische Blei-ZinkVererzung und mitteltertiäre, hydrothermale Karbonatzementation. Arch f Lagerst forsch Geol B-A 18:57-116

Leach DL, Bechstädt T, Boni M, Zeeh S (2003) Triassic-hosted Mississippi Valley-type zinc-lead ores of Poland, Austria, Slovenia, and Italy. In: Ashton J, Boland M, Cruise M, Earls G, Fusciardi L, Kelly J, Stanley G (eds) Andrew C. Europe's Major Base Metal Deposits, Irish Association of Economic Geologists (IAEG), pp 169-213

Leach DL, Sangster DF, Kelley KD, Large RR, Garven G, Allen CR, Gutzmer J, Walters S (2005) Sediment-hosted lead-zinc deposits: a global perspective. Econ Geol $100^{\text {th }}$ Anniversary Vol 561-607

Liebminger A, Haberhauer G, Papesch W, Heiss G (2006) Correlation of the isotopic composition in precipitation with local conditions in alpine regions. J Geoph Res 111:1-10

Longinelli A, Anglesio E, Flora O, Iacumin P, Selmo E (2006) Isotopic composition of precipitation in Northern Italy: reverse effect of anomalous climatic events. J Hydrol 329:471-476

Melcher F, Henjes-Kunst F, Henjes-Kunst E, Schneider J, Thöni M (2010) Erste Rb-Sr Isotopendatierung an Sphalerit der Zn-Pb Lagerstätte Bleiberg (Kärnten), sowie Sr und Sm-NdIsotopendaten von kogenetischem Karbonat und Fluorit. PANGEO 2010, Leoben. Conference abstract. J Alpine Geol 52:178-180

Mondillo N, Boni M, Balassone G, Joachimski M, Mormone A (2014) The Jabali nonsulphide $\mathrm{Zn}-\mathrm{Pb}-\mathrm{Ag}$ deposit, western Yemen. Ore Geol Rev 61:248-267 
Omenetto P (1966) Il giacimento piombo-zincifero di Oltre il Colle (Alpi Bergamasche). Mem Ist Geol Min Univ Padova 25:3-49

Omenetto P (1979) Significant ore fabric relationships in the lead, zinc, fluorite and barite deposits of the Triassic province (Italian Southern Alps). An Soc Géol Belgique 102:519-529

Ostendorf J, Henjes-Kunst F, Mondillo N, Boni M, Schneider J, Gutzmer J (2015) Formation of Mississippi Valley-type deposits linked to hydrocarbon generation in extensional tectonic settings: evidence from the Jabali $\mathrm{Zn}-\mathrm{Pb}-(\mathrm{Ag})$ deposit (Yemen). Geology 43(12): $1055-1058$

Radke BM, Mathis RL (1980) On the formation and occurrence of saddle dolomite. J Sediment Petrol 50:1149-1168

Reichert J, Borg G (2008) Numerical simulation and a geochemical model of supergene carbonate-hosted nonsulphide zinc deposits. Ore Geol Rev 33:134-151

Reverman RL, Fellin MG, Herman F, Willett SD, Fitoussic C (2012) Climatically versus tectonically forced erosion in the Alps: Thermochronometric constraints from the Adamello complex, Southern Alps, Italy. Earth Planet Sc Let 339-340:127-138

Rodeghiero F (1977) Le mineralizzazioni a Pb-Zn, fluorite, barite nel carnico della zone del Pizzo della Presolana. Boll Ass Min Sudalpina, anno XIV 3-4:453-474

Rodeghiero F, Vailati G (1978) Nuove osservazioni sull'assetto geologico-strutturale del settore centrale del distretto piombozincifero di Gorno (Alpi Bergamasche). L'Industria Mineraria 29: 298-302

Ronchi P, Jadoul F, Savino R (2004) Quaternary dedolomitization along fracture systems in a Late Triassic dolomitized platform (western southern Alps, Italy). Carbonates Evaporites 19:51-66

Sangster DF (1976) Carbonate-hosted lead-zinc deposits. In: Wolf KH (ed) Handbook of stratabound and stratiform ore deposits, vol 6, pp $447-456$

Schmid SM, Aebli HR, Heller F, Zingg A (1989) The role of the periadriatic line in the tectonic evolution of the Alps. In: Coward MP, Dietrich D, Park RG (eds) Alpine tectonics, vol 45. Geological Society of London: Special Publications, London, pp 153-171

Schroll E (2005) Alpine type Pb-Zn-deposits (APT) hosted by Triassic carbonates. In: Mao J, Bierlein FP (eds) Mineral deposit research: meeting the global challenge, Springer Berlin 1:175-178

Schroll E (2006) Neues zur Genese der Blei-Zink Lagerstätte Bleiberg. Carinthia II 196/116 Jahrgang, 483-500
Schulz O (1964) Lead-zinc deposits in the calcareous Alps as an example of submarine hydrothermal formation of mineral deposits. Devel Sediment 2:47-52

Suc J-P, Popescu S-M, Fauquette S, Bessedik M, Jiménez-Moreno G, Bachiri Taoufiq N, Zheng Z, Medail F, Klotz S (2018) Reconstruction of Mediterranean flora, vegetation and climate for the last 23 million years based on an extensive pollen dataset. Ecol Mediterr 44:53-85

Takahashi T (1960) Supergene alteration of zinc and lead deposits in limestone. Econ Geol 55:1083-1115

Vaché R (1962) Feinstratigraphische Untersuchungen an den erzführenden Schichten der Lagerstätte von Gorno (Bergamasker Alpen). Diss Z Erl Doktorgr, München, $88 \mathrm{p}$

Vailati G (1966) Concentrazioni di minerali di piombo e zinco legate a fenomeni tettonici nel giacimento di Gorno. Simp Int Giacim Min d Alpi, Trento-Mendola 11-18 Settembre 1966 183-204

Willett SD (2010) Late Neogene Erosion of the Alps: a climate driver? Ann Rev Earth Planet Sc 38:411-437

Winterer EL, Bosellini A (1981) Subsidence and sedimentation on Jurassic passive continental margin. Am Ass Petroleum Geol Bull 65:394-421

Zanchetta S, Malusà MG, Zanchi A (2015) Precollisional development and Cenozoic evolution of the Southalpine retrobelt (European Alps). Lithosphere 7:662-681

Zanchi A, Chinaglia N, Conti M, De Toni S, Ferliga C, Tsegaye A et al (1990) Analisi strutturale lungo il fronte della Dolomia Principale in bassa Val Seriana (Bergamo). Mem Soc Geol It 45:83-92

Zanchi A, D'Adda P, Zanchetta S, Berra F (2012) Syn-thrust deformation across a transverse zone: the Grem-Vedra fault system (central Southern Alps, N Italy). Swiss J Geosc 105:19-38

Zeeh S, Kuhlemann J, Bechstädt T (1998) The classical Pb-Zn deposits of the Eastern Alps (Austria/Slovenia) revisited: MVT deposits resulting from gravity driven fluid flow in the Alpine Realm. Geologija 41:257-273

Zucchetti S (1960) Sulla genesi dei depositi piombo-zinciferi nel Metallifero del Bergamasco. Estr Boll Serv Geol It 82:25-88

Publisher's note Springer Nature remains neutral with regard to jurisdictional claims in published maps and institutional affiliations. 